\title{
PERFORMANCE OF MASONRY BUILDINGS AND CHURCHES IN THE 22 FEBRUARY 2011 CHRISTCHURCH EARTHQUAKE
}

\author{
Dmytro Dizhur ${ }^{1}$, Jason Ingham ${ }^{2}$, Lisa $_{\text {Moon }}^{3}$, Mike Griffith ${ }^{4}$, \\ Arturo Schultz ${ }^{5}$, Ilaria Senaldi ${ }^{6}$, Guido Magenes, \\ Jocelyn Dickie ${ }^{8}$, Shelley Lissel ${ }^{9}$, Jose Centeno ${ }^{10}$, \\ Carlos Ventura ${ }^{11}$, Joao Leite $^{12}$ and Paulo Lourenco ${ }^{13}$
}

\begin{abstract}
SUMMARY
As part of the 'Project Masonry' Recovery Project funded by the New Zealand Natural Hazards Research Platform, commencing in March 2011, an international team of researchers was deployed to document and interpret the observed earthquake damage to masonry buildings and to churches as a result of the $22^{\text {nd }}$ February 2011 Christchurch earthquake. The study focused on investigating commonly encountered failure patterns and collapse mechanisms. A brief summary of activities undertaken is presented, detailing the observations that were made on the performance of and the deficiencies that contributed to the damage to approximately 650 inspected unreinforced clay brick masonry (URM) buildings, to 90 unreinforced stone masonry buildings, to 342 reinforced concrete masonry (RCM) buildings, to 112 churches in the Canterbury region, and to just under 1100 residential dwellings having external masonry veneer cladding. In addition, details are provided of retrofit techniques that were implemented within relevant Christchurch URM buildings prior to the $22^{\text {nd }}$ February earthquake and brief suggestions are provided regarding appropriate seismic retrofit and remediation techniques for stone masonry buildings.
\end{abstract}

\section{INTRODUCTION}

In the early morning of $4^{\text {th }}$ September 2010 the region of Canterbury, New Zealand, was subjected to a magnitude M7.1 earthquake. The epicentre was located near the town of Darfield, $40 \mathrm{~km}$ west of the city of Christchurch. This was the

\begin{abstract}
country's most damaging earthquake since the 1931 Hawke's Bay earthquake [1]. Since $4^{\text {th }}$ September 2010 the region has been subjected to thousands of aftershocks, including several more damaging events such as a magnitude M6.3 aftershock on $22^{\text {nd }}$ February 2011. Although of a smaller magnitude, the earthquake on $22^{\text {nd }}$ February produced peak ground
\end{abstract}

\footnotetext{
${ }^{1}$ PhD Candidate, Dept. of Civil and Environmental Engineering, The University of Auckland, Auckland, New Zealand

${ }^{2}$ Assoc. Professor, Dept. of Civil and Environmental Engineering, The University of Auckland, Auckland, New Zealand

${ }^{3}$ PhD Candidate, School of Civil, Environmental and Mining Engineering, The University of Adelaide, Adelaide, Australia

${ }^{4}$ Professor, School of Civil, Environmental and Mining Engineering, The University of Adelaide, Adelaide, Australia

${ }^{5}$ Professor, Dept. of Civil Engineering, The University of Minnesota, Minneapolis, United States of America

${ }^{6}$ PhD Candidate, Centre for Post-graduate Training and Research in Earthquake Engineering \& Engineering Seismology (ROSE School), Pavia, Italy

${ }^{7}$ Assoc. Professor, Dept. of Structural Mechanics, The University of Pavia, Italy

${ }^{8}$ PhD Candidate, Dept. of Civil Engineering, The University of Calgary, Canada

${ }^{9}$ Assoc. Professor, Dept. of Civil Engineering, The University of Calgary, Canada

${ }^{10}$ PhD Candidate, Dept. of Civil Engineering, The University of British Columbia, Vancouver, Canada

${ }^{11}$ Professor, Dept. of Civil Engineering, The University of British Columbia, Vancouver, Canada

${ }^{12}$ PhD Candidate, Dept. of Civil Engineering, The University of Minho, Guimarães, Portugal

${ }^{13}$ Professor, Dept. of Civil Engineering, The University of Minho, Guimarães, Portugal
} 
accelerations in the Christchurch region that were substantially greater than those measured during the $4^{\text {th }}$ September earthquake and in some locations generated shaking intensities greater than twice the design level $[2,3]$. Whilst in September 2010 most earthquake shaking damage was limited to unreinforced masonry (URM) buildings, in February 2011 all types of buildings sustained damage. Temporary shoring and strengthening techniques applied to buildings following the Darfield earthquake were tested in February 2011. In addition, two large aftershocks (magnitudes M5.7 and M6.2) occurred on $13^{\text {th }}$ June 2011, further damaging many already weakened structures.

Commencing in March 2011 an international team of researchers was deployed to document and interpret the observed earthquake damage to masonry buildings and to churches, by investigating the failure patterns and collapse mechanisms that were commonly encountered. This initiative was undertaken as part of the 'Project Masonry' Recovery Project funded by the New Zealand Natural Hazards Research Platform.

A brief summary of activities undertaken as part of Project Masonry is presented, detailing the observations that were made on the performance and the deficiencies that contributed to the observed damage of:

- Unreinforced clay brick masonry (URM) buildings, and earthquake strengthening (or seismic retrofitting) techniques that were implemented within relevant Christchurch URM buildings prior to the $22^{\text {nd }}$ February earthquake;

- Unreinforced stone masonry buildings (including brief suggestions on appropriate seismic retrofit and remediation techniques);

- $\quad$ Reinforced concrete masonry (RCM) buildings, including specific case study RCM buildings;

- Churches in the Canterbury region;

- Residential dwellings having external masonry veneer cladding.

\section{UNREINFORCED CLAY BRICK MASONRY BUILDINGS}

Unreinforced masonry buildings are known to behave poorly in large earthquakes. In New Zealand the majority of the existing URM building stock was constructed before the 1931 Hawke's Bay earthquake, and represents a significant proportion of New Zealand's architectural historic [4]. Over 650 unreinforced clay brick masonry buildings were inspected in the Christchurch area from March 2011 onwards, with the distribution of the inspected URM buildings illustrated in Figure 1. While some of the buildings that were more severely damaged in September 2010 had been demolished prior to February 2011, many more had received temporary shoring and strengthening, and a number of these buildings were barricaded and hence unoccupied at the time of the $22^{\text {nd }}$ February 2011 earthquake. The damage to unreinforced and retrofitted clay brick masonry buildings in the $4^{\text {th }}$ September 2010 Darfield earthquake was reported previously by Dizhur et al. [5] and by Ingham and Griffith [6].

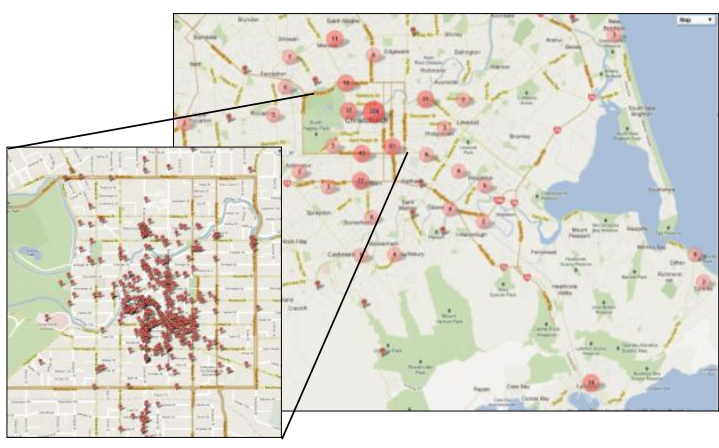

Figure 1: Location of inspected URM buildings.

\section{Building demolition statistics}

In the period between $22^{\text {nd }}$ February and $25^{\text {th }}$ July 2011 almost 200 URM buildings were demolished [7]. These 200 URM buildings account for approximately $85 \%$ of all buildings demolished during this time. Of those URM buildings that remain, few are currently in an occupiable condition. An example of the extensive demolition of URM buildings that took place following the $13^{\text {th }}$ June aftershock is presented in Figure 2.

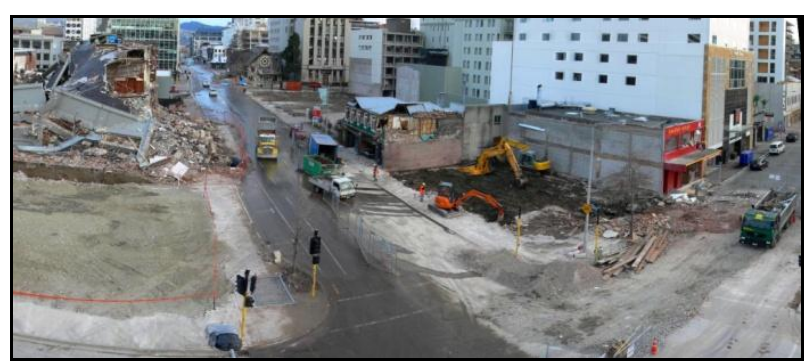

Figure 2: Extensive building demolition following the $13^{\text {th }}$ June 2011 aftershock.

\section{Material properties}

Brick and mortar samples were collected from Christchurch URM buildings following the $4^{\text {th }}$ September 2010 and $22^{\text {nd }}$ February 2011 earthquakes. The mortar was typically lime based mortar, which due to low compressive strength could be crumbled by finger pressure. The average normalised compressive strength of the 293 mortar samples collected from 61 URM building sites in Christchurch was found to be 2.6 $\mathrm{MPa}$, with a strength range from $0.45 \mathrm{MPa}$ to $25.3 \mathrm{MPa}$. It is expected that the highest readings were for samples containing modern cement mortar used in repointing (remediation) of existing mortar joints, rather than being associated with historic or original mortar. The average compressive strength of 67 clay bricks extracted from 23 URM building sites in Christchurch resulted in an average compressive strength of $24.2 \mathrm{MPa}$, and ranged from 9.5 MPa up to $39.1 \mathrm{MPa}$.

\section{Failure types}

\section{Chimney, Gable and parapet failures}

Many unreinforced masonry chimneys throughout the Christchurch region collapsed during the Darfield earthquake on $4^{\text {th }}$ September 2010 , or during the subsequent week of large aftershocks $[5,8]$. Of those chimneys that remained standing, either damaged or undamaged, many were demolished, or alternatively attempts were made to strengthen them. Therefore, by the time of the $22^{\text {nd }}$ February 2011 earthquake there were few URM chimneys left to collapse. Damage to and failure of gable walls and parapets was common in September 2010 , and was again widely seen after the $22^{\text {nd }}$ February 2011 earthquake. 


\section{Out-of-plane wall collapse}

Out-of-plane wall collapse was the most commonly observed failure to clay brick URM buildings following the $22^{\text {nd }}$ February 2011 earthquake, with many two-storey buildings losing their entire front façades or upper storey walls (see Figure 3).

Two primary types of out-of-plane wall failures were observed:

- Vertical (or one-way) bending of the wall, which tended to occur in longer walls or walls without side supports (see Figure 4);

- Two-way bending, which required support of at least one vertical edge of a wall (see Figure 5).

Cantilever type out-of-plane failure with the entire top section of a wall or building façade collapsing (see example in Figure 3) was commonly observed. However, when the top section of the wall was well connected to diaphragms, failures in both vertical and two-way bending were observed.

\section{Cavity construction}

Cavity construction refers to a form of wall construction where an air gap is left between leaves or wythes of brick, and during post-earthquake inspections cavity construction was encountered in almost half of the URM buildings surveyed in Christchurch, with the remainder having solid interconnected multi-leaf walls. A single leaf of outer clay brick veneer is the most common type of cavity construction, with the inner section being two or more leaves thick. Double leaf construction on each side of the cavity was also observed. Leaves on either side of a cavity are typically held together by regularly spaced metal cavity ties but in the case of poor connection between the leaves the outer veneer layer can 'peel' separately, as illustrated in Figure 6. It was commonly observed that cavity ties in failed cavity walls had deteriorated and were in poor condition due to corrosion, as shown in Figure 7 and Figure 8. Out-of-plane failure of the veneer was typically attributed to either the deteriorated condition of the metal ties or to pullout of the ties from the mortar bed joints due to the use during construction of weak lime mortar.

\section{In-plane wall failures}

Damage occurring in the plane of URM walls was widely observed, including:

- Diagonal shear cracking in piers, spandrels and walls;

- Shear sliding on mortar bed joints or between storeys;

- In-plane rocking and toe crushing of piers.

Diagonal shear cracking was observed in piers, spandrels and walls. Figure 9 shows shear cracking in piers and diagonal and vertical cracking through spandrels, and a representative example of diagonal shear cracking through a URM pier is illustrated in Figure 10. Examples were observed of unperforated URM walls that sustained major shear cracking, as illustrated in Figure 11. Although not as common as diagonal shear failures, examples of bed joint shear sliding of URM walls were also observed. Rocking was observed for cases where URM piers had a higher aspect ratio and lower levels of overburden. Only a few cases of the toe crushing failure mechanism, as illustrated in Figure 12, were observed.

\section{Directionality and Shaking Duration}

In a large number of cases in the Christchurch Central Business District (CBD) in-plane wall damage was observed on the north and south facing walls, while out-of-plane damage to the eastern and western walls was observed. This damage pattern, as shown in Figure 13, indicates that in the
CBD the direction of shaking on $22^{\text {nd }}$ February 2011 was predominantly east-west.

Another interesting observation following the $22^{\text {nd }}$ February 2011 earthquake was that many walls were on the verge of collapse. Most noticeable were walls where individual bricks were seen to be on the verge of dislodgement. Had the severe shaking lasted longer, these bricks may have become dislodged, resulting in further wall failures. The damage progression of a URM wall in the September 2010, February 2011 and June 2011 earthquakes is illustrated in Figure 14.

\section{Diaphragm Deformations and Pounding Damage}

Little technical information is currently available on the structural characteristics of flexible timber diaphragms within unreinforced masonry buildings. Following the $22^{\text {nd }}$ February 2011 earthquake it became possible to inspect timber diaphragms within buildings from the safety of the street because of the large number of URM walls that had collapsed out-of-plane, and in many cases these diaphragms were observed to be in a deteriorated condition. As many of the URM buildings in Christchurch had timber floor and roof diaphragms, the performance of such buildings in the recent earthquakes presents a unique opportunity to develop an improved understanding of the role of flexible diaphragm on the overall seismic behaviour of URM buildings.

Evidence of diaphragm movement was seen in many buildings, and the effect of diaphragm deformations on wall response varied from cracked plaster to complete wall collapse. As shown in Figure 15, excessive lateral movement of the timber roof diaphragm has displaced the external perimeter walls of this building beyond their out-of-plane deflection capacity and resulted in wall collapse.

Pounding damage was commonly seen in tightly spaced buildings in the CBD and in many cases pounding appears to have been the loading condition principally responsible for inplane wall failures. Figure 16 shows an example of pounding damage to adjacent URM buildings.

\section{Ground Deformations}

The $4^{\text {th }}$ September 2010 earthquake resulted in significant ground deformations in many locations in Christchurch, due to liquefaction located primarily in the eastern suburbs and lateral spreading occurring near river banks. The aftershocks on both $22^{\text {nd }}$ February and $13^{\text {th }}$ June 2011 caused further damage in these areas. Therefore in addition to shaking damage some buildings sustained damage from lateral ground spreading and differential settlement due to liquefaction. Figure 17 shows the internal floor damage to a URM building located in a region that developed extreme liquefaction.

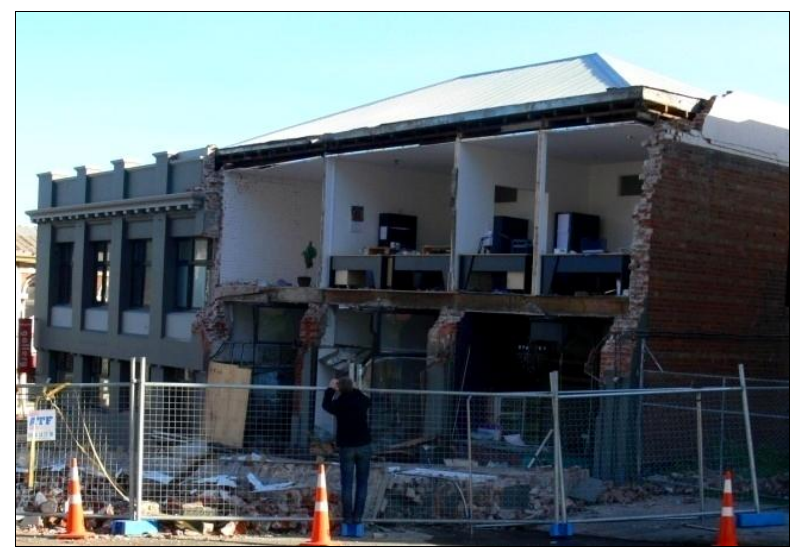

Figure 3: Out-of-plane collapse of parapet and façade, Lyttelton. 


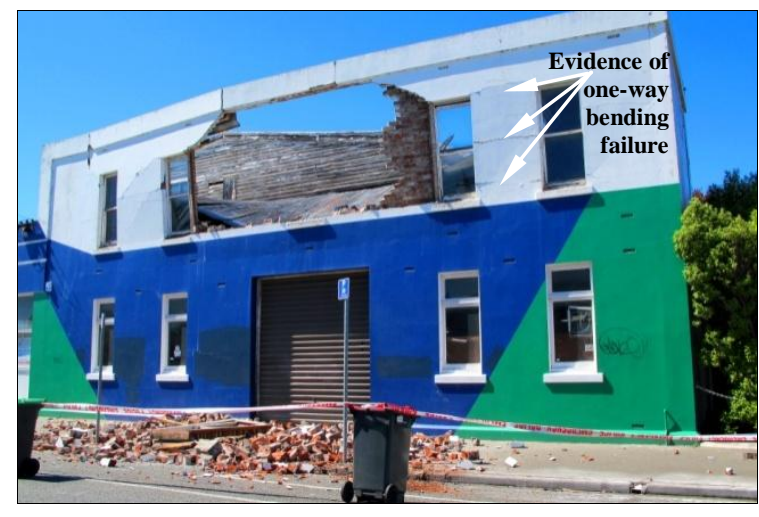

Figure 4: One-way bending out-of-plane wall failure below a concrete ring beam.

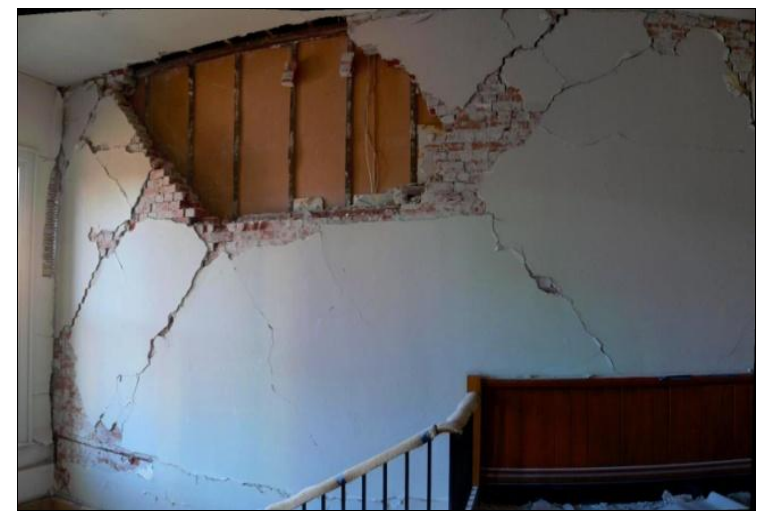

Figure 5: Two-way bending out-of-plane wall failure.

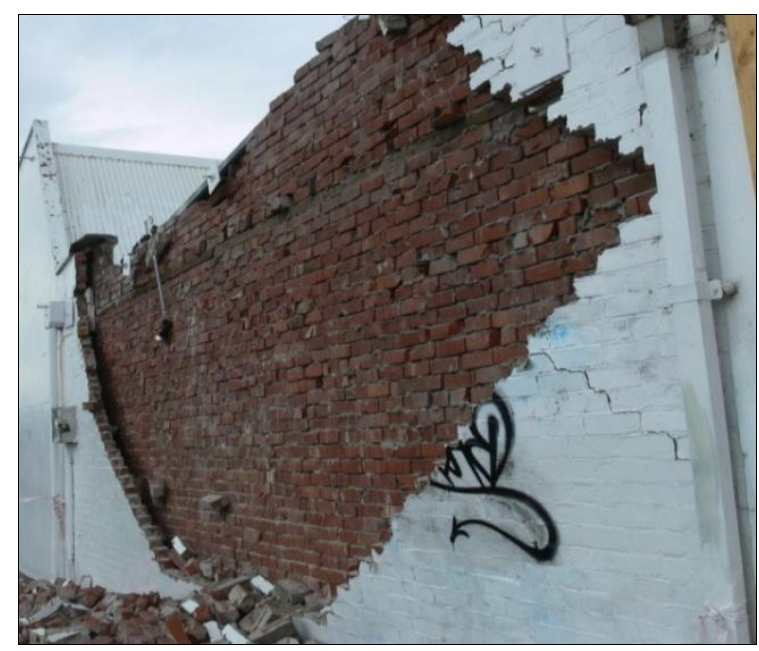

Figure 6: Out-of-plane failure of a single leaf veneer.

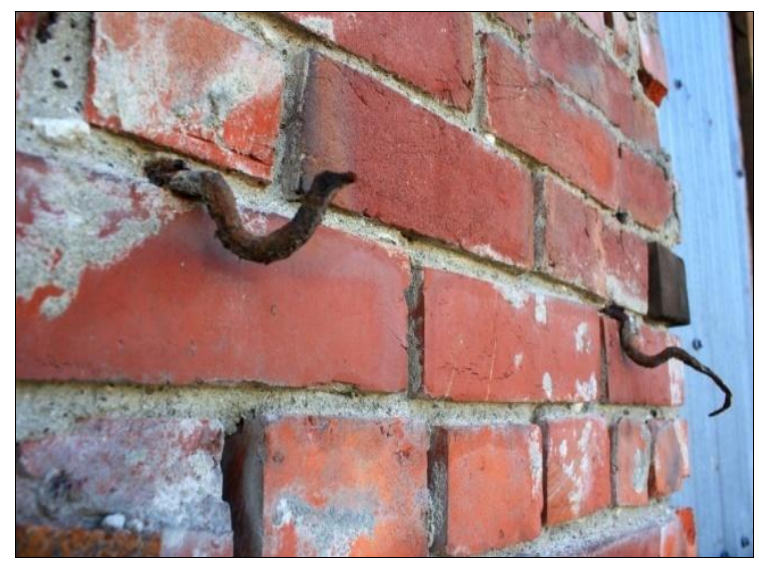

Figure 7: Metal cavity ties in poor rusted condition.

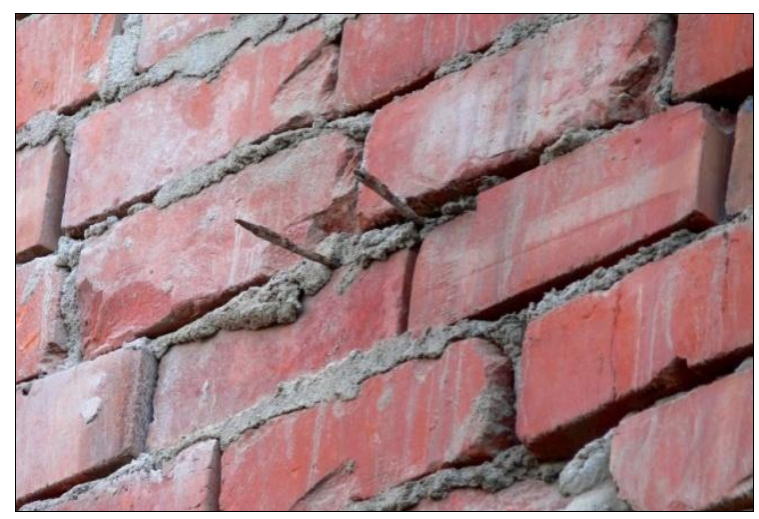

Figure 8: Deteriorated "horseshoe" shaped wire cavity tie.

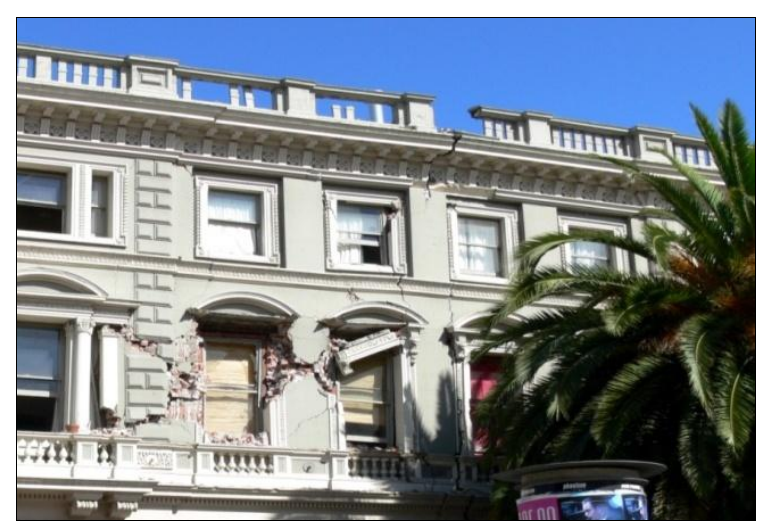

Figure 9: Diagonal shear cracking through piers and spandrels.

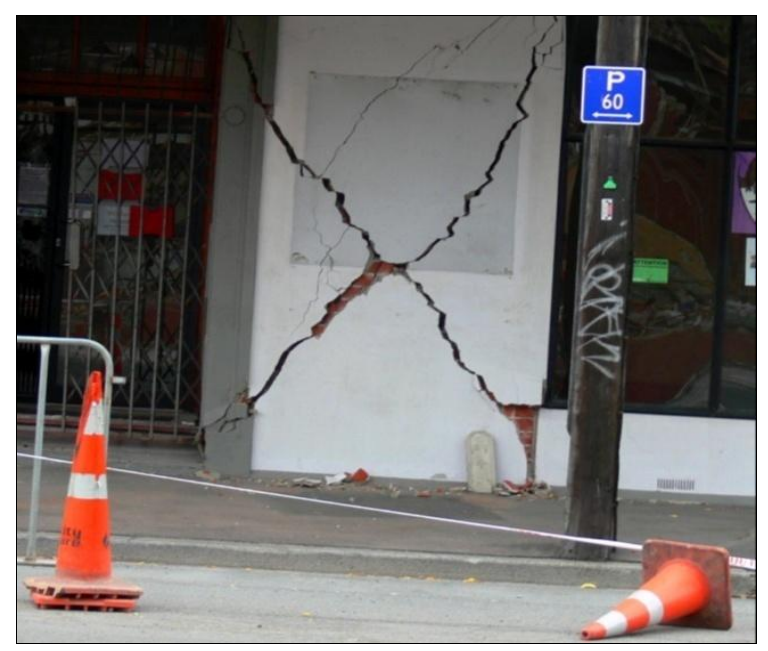

Figure 10: Diagonal shear cracking through piers.

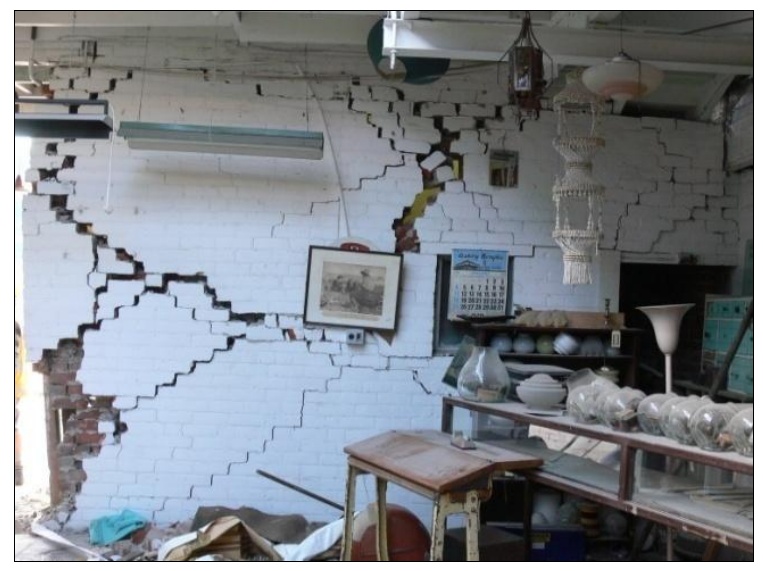

Figure 11: Diagonal shear cracking of unperforated wall. 


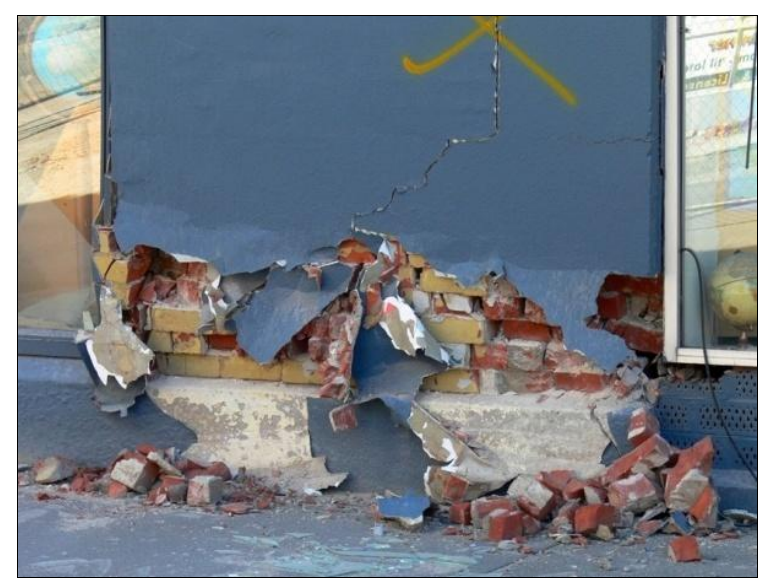

Figure 12: Close-up of toe crashing failure mechanism.

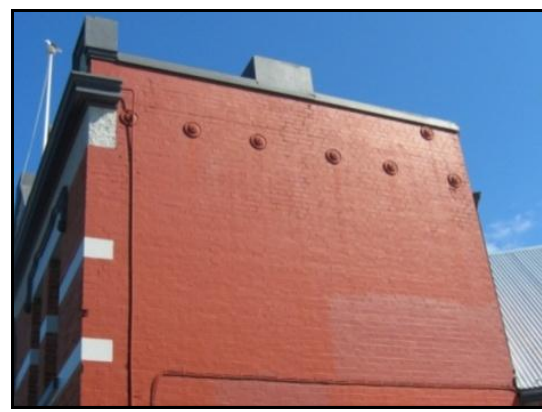

(a) Post-September 2010 - minor visible damage

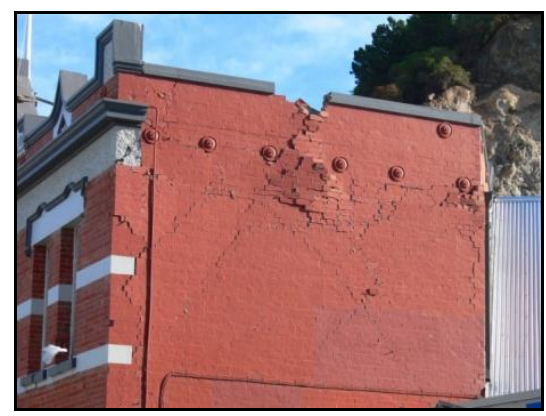

(b) Post-February 2011 - section of masonry on verge of collapse

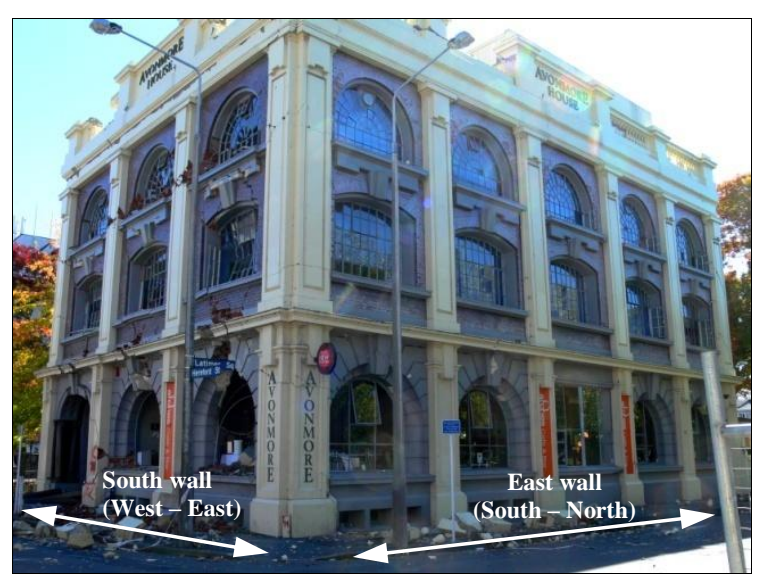

Figure 13: South east corner - shear cracking only visible on south face.

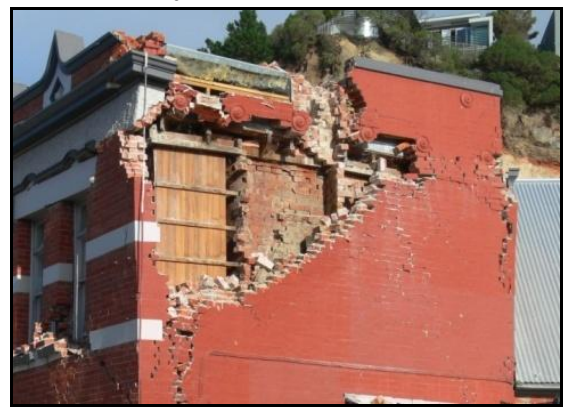

(c) Post-June 2011 - collapse of the wall

Figure 14: Progressive building damage.

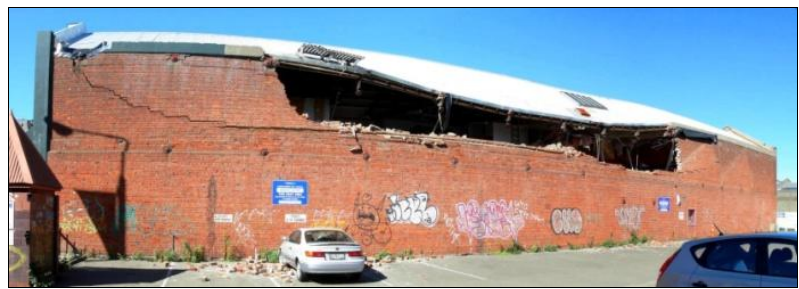

(a) Side view of building

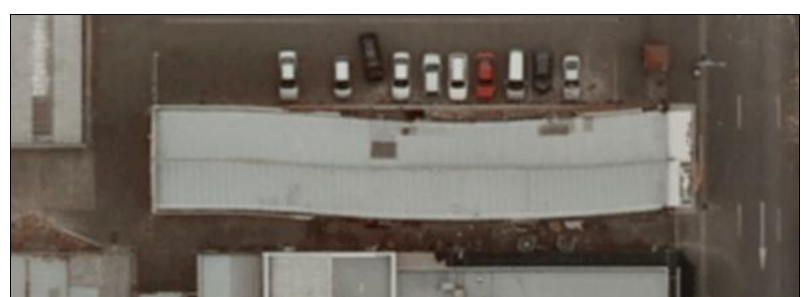

(b) Aerial view of building

Figure 15: Out-of-plane wall failure due to excessive roof diaphragm movement.

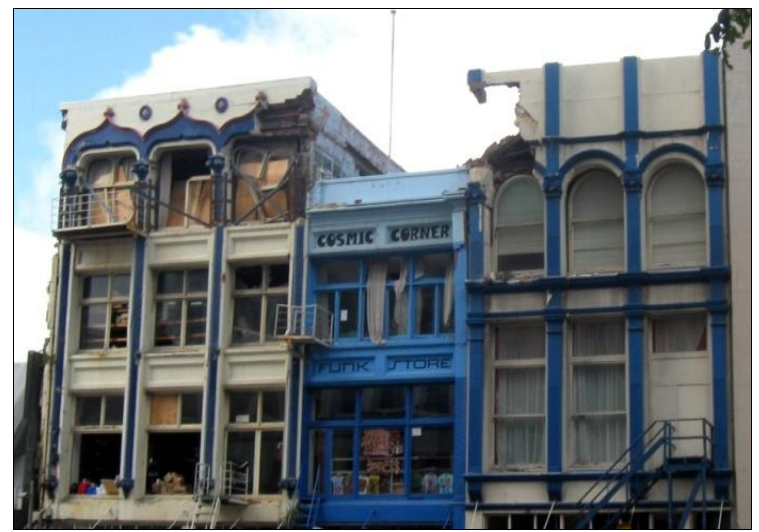

Figure 16: Pounding between three buildings, causing inplane failure in URM buildings.

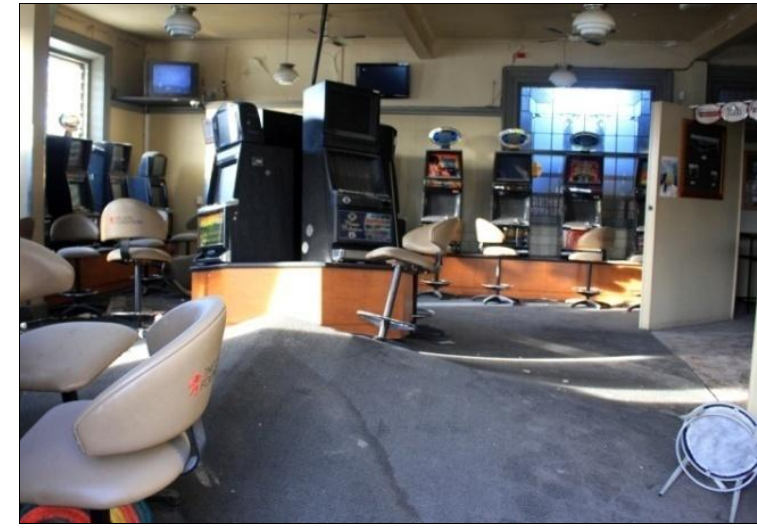

Figure 17: Extreme floor movement due to severe differential ground deformation. 


\section{EARTHQUAKE STENGTHENED CLAY BRICK URM BUILDINGS}

Of the buildings surveyed, the performance of earthquake strengthened (seismically retrofitted) URM buildings varied greatly. A large number of retrofitted URM buildings showed severe signs of earthquake damage, whilst only a few retrofitted URM buildings showed little visible evidence of earthquake damage and were deemed to be safe to occupy after the earthquake.

Insufficient or poorly performing connections were one of the main contributors to failure of earthquake strengthened URM buildings, as described in more detail in the following section. In most cases, installed retrofits prevented entire building collapse, allowing occupants to safely evacuate the buildings once strong ground shaking had ended. Some of the more common types of seismic retrofits observed in Christchurch URM buildings were:

- Steel moment frames, which increased the lateral capacity of a building (see Figure 18);

- Steel strong-backs, which helped to prevent out-of-plane failure of URM walls (see Figure 19 and 20);

- Application of shotcrete, which increased the in-plane and out-of-plane wall strength (see Figure 21).

Less common retrofit types were also observed, with an example being the in-plane strengthening of wall sections using diagonally oriented steel straps anchored into the wall. As shown in Figure 22, the masonry restrained by this retrofit sustained considerable damage when compared to the observed condition following the $4^{\text {th }}$ September earthquake, as reported by Dizhur et al. [5].

Retrofits that generally performed well were:

- Well conceived designs which aimed to reduce torsional effects and tied the masonry together;

- Well connected steel strong-backs and steel moment frames.

Buildings that were well maintained over their life generally performed better than their less well maintained equivalent as a weathertight building envelope reduces the rate of progressive deterioration due to water ingress to masonry and to timber diaphragms.

The veneer of the building shown in Figure 23 was retrofitted using inserted high strength twisted stainless steel (SI) rods to tie the veneer to the main structural walls. Following the earthquake on the $22^{\text {nd }}$ February 2011, these SI rods showed signs of movement, with the SI rod cover pushed out or becoming completely dislodged. These observations suggest that differential movement occurred between the leaves on either side of the cavity. The outer veneer leaf of the wall collapsed during the $13^{\text {th }}$ June 2011 aftershock.

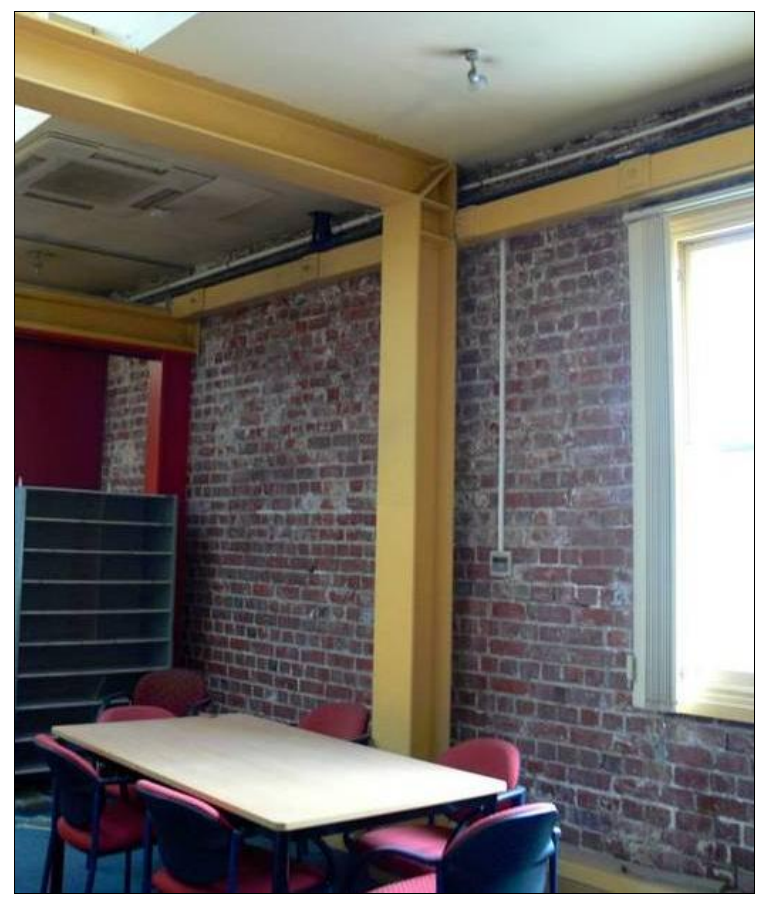

Figure 18: Internal view of steel moment frame retrofit.

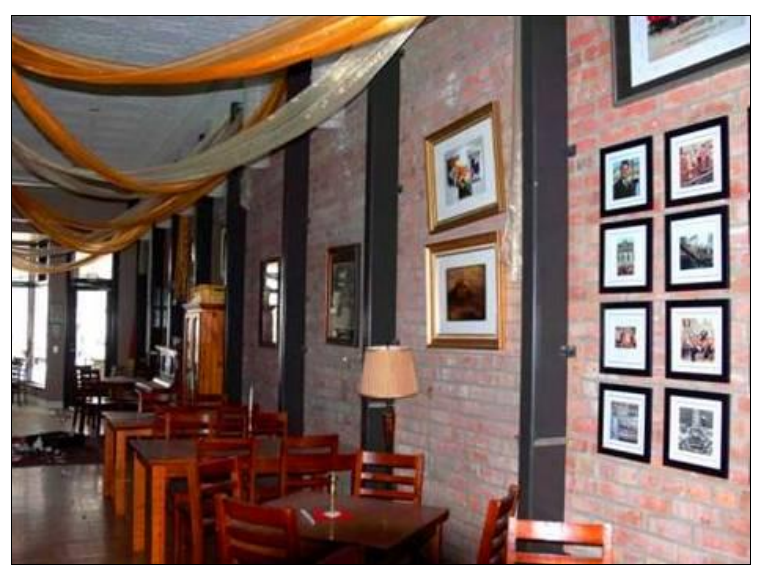

Figure 19: Steel strong-backs provided out-of-plane support for URM walls.

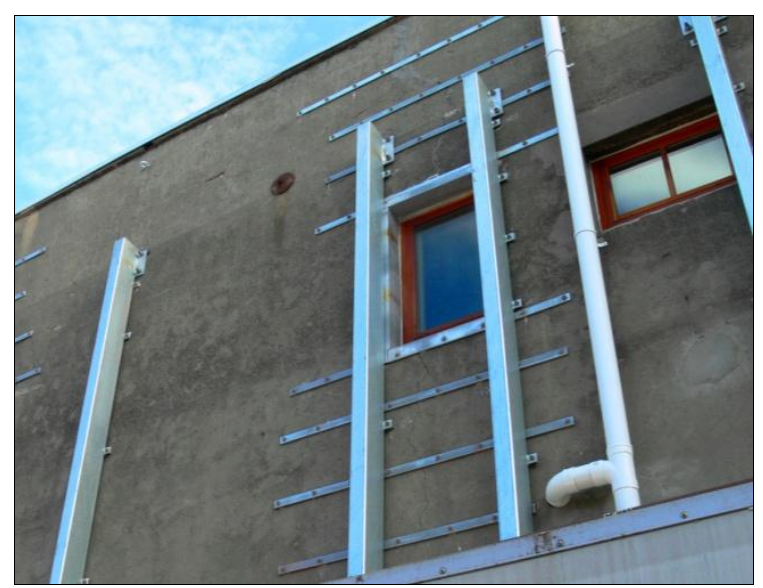

Figure 20: Externally positioned steel strong backs prevented out-of-plane failure of a tall and slender URM wall. 


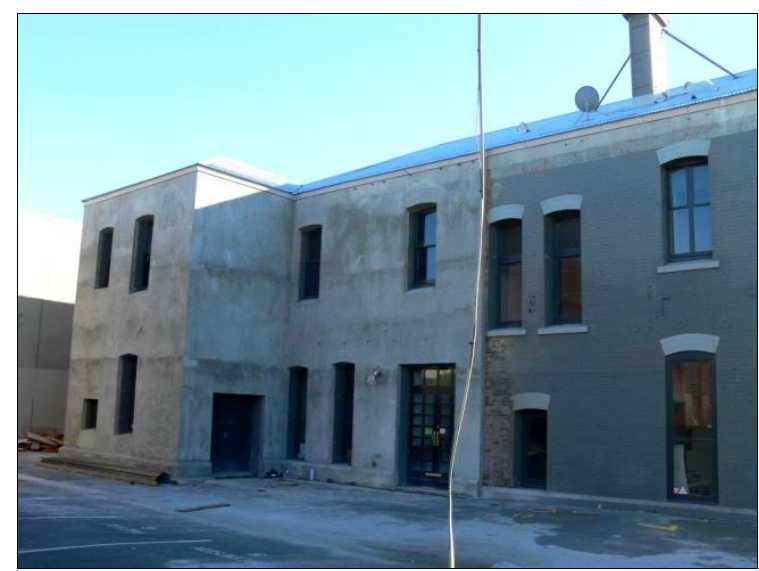

Figure 21: Rear of a building retrofitted using shotcrete.

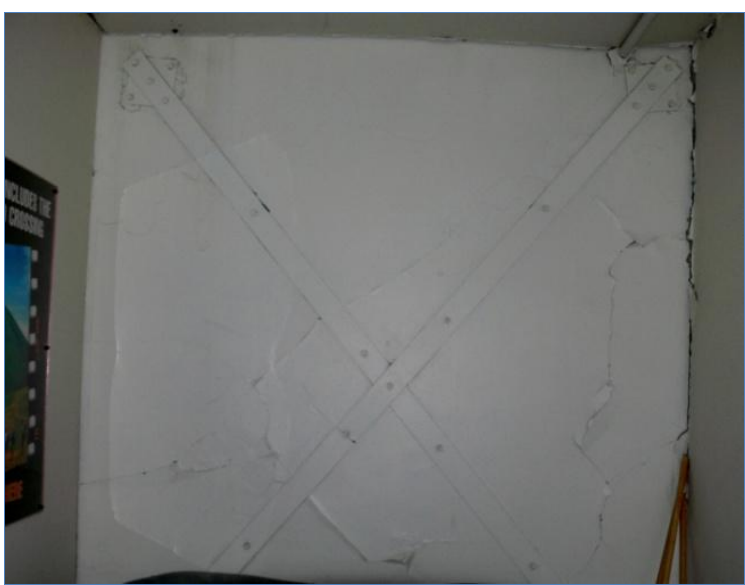

Figure 22: ' $X$ ' steel bracing retrofit with extensively cracked masonry.

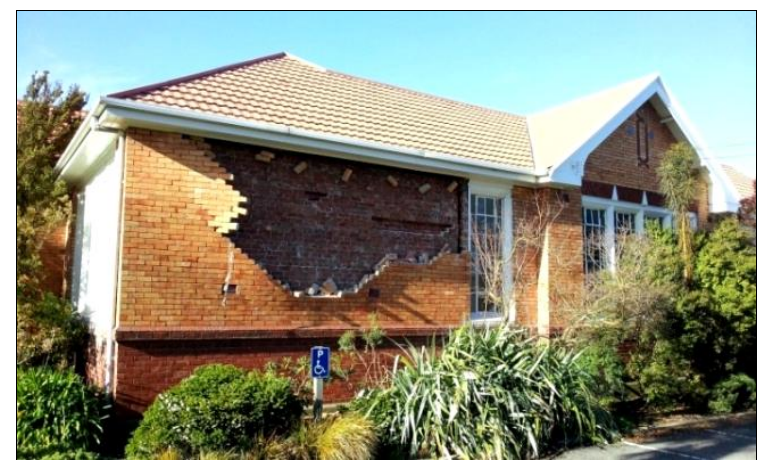

Figure 23: Post June 2011 condition of a veneer layer tied using inserted high strength twisted stainless steel rods.

\section{Performance of Anchor Connections}

The connections between flexible timber diaphragms and URM buildings are critical building components that must perform adequately before the desirable seismic response of URM buildings may be achieved. These connections typically consist of steel anchors installed either at the time of construction or post construction. In addition to walldiaphragm connections, similar anchorage systems are also used for parapet bracing and veneer restraint.

Field observations made during the initial reconnaissance and the subsequent damage surveys of clay brick URM buildings in Christchurch following the 2010/2011 earthquakes revealed numerous cases where anchor connections joining masonry walls or parapets with roof or floor diaphragms appeared to have failed prematurely. These observations were more frequent for the case of adhesive anchors than for the case of through-bolt connections (i.e. anchorages having plates on the exterior façade of the masonry walls). Punching shear failure was the most common failure type observed, and was mainly attributable to mortar failure as shown in Figure 24. In Figure 25 it is shown that the successful performance of anchors does not necessarily prevent out-of-plane wall failure, as the potential for one or two way out-of-plane wall bending failure is not necessarily precluded.

Due to long term deterioration from environmental exposure, numerous cases of reduction of anchorage cross-sectional area were observed. An example of adhesive anchors installed between a URM wall and a degraded roof diaphragm which had badly deteriorated due to severe water ingress is shown in Figure 26. The construction quality of adhesive type anchorages was commonly observed to be poor, due to insufficient anchorage depths and poor workmanship, as shown in Figure 29.

Most of the adhesive anchor systems that were observed used threaded steel rods ranging from $10 \mathrm{~mm}$ to $16 \mathrm{~mm}$ in diameter. These rods were embedded in the masonry wall to a depth equal to the wall thickness less $25-50 \mathrm{~mm}$. Although less common, deformed reinforcement bars with a diameter of up to $20 \mathrm{~mm}$ and with one threaded end were also observed to be used in adhesive anchor systems. Although at times hard to identify, there appears to be little evidence suggesting the use of bent anchors (having an angle of minimum $22.5^{\circ}$ to the perpendicular projection from the wall surface), and the majority of observed anchors were positioned horizontally.

The out-of-plane failure of URM walls was in many cases also attributed to the low shear strength of masonry (see Figure 27), wide anchorage spacing (see Figure 28) and/or insufficient embedment depth of anchors. In some cases, the reasons for the adhesive anchor failures were apparent. As shown in Figure 29, the top anchor shown is an example of anchor pullout due to insufficient embedment length, while the remaining anchors shown in Figure 29 indicate a lack of bonding between the anchor and the base material. In other cases, the reasons for such failures were not evident from visual observation. Consequently, an in-field test program was undertaken in an attempt to evaluate the performance of adhesive anchor connections between roof or floor diaphragm and unreinforced clay brick masonry walls.

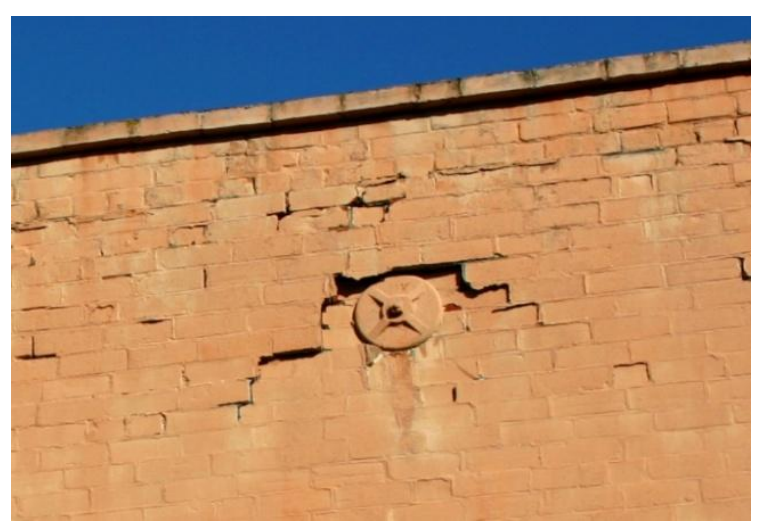

Figure 24: Anchor on the verge of punching shear failure. 


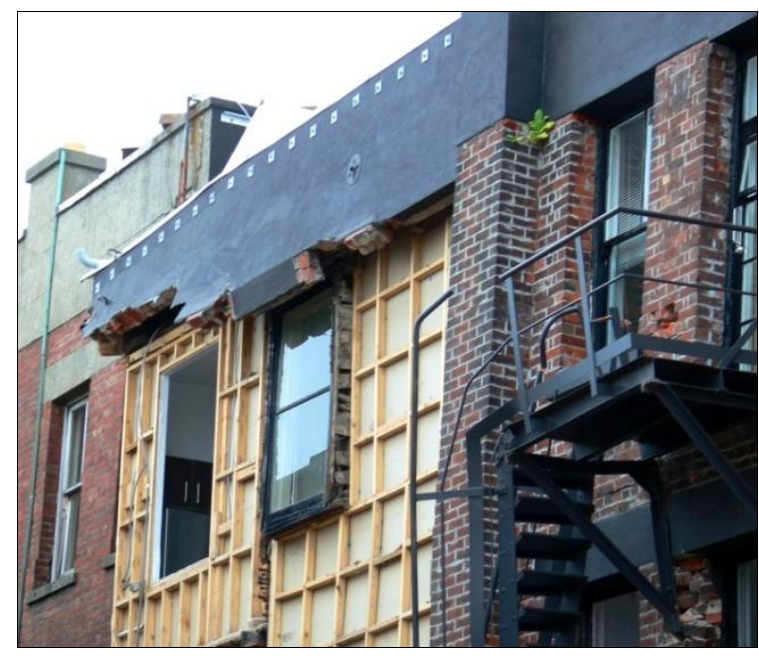

Figure 25: Row of successful wall-diaphragm anchors, with wall failure beneath.

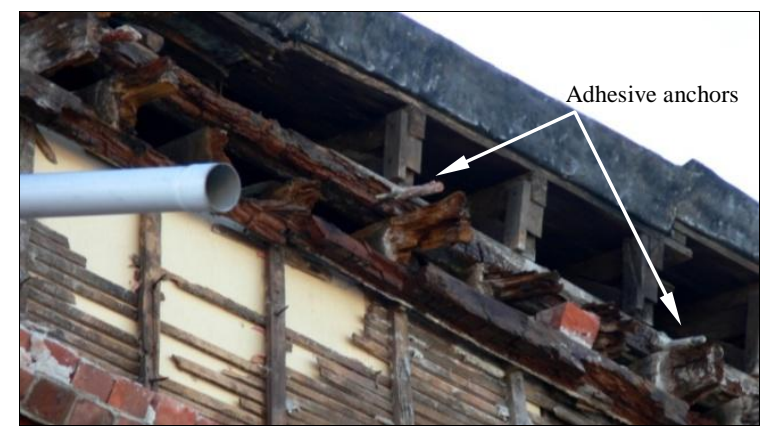

Figure 26: Adhesive anchors installed in a badly deteriorated roof diaphragm.

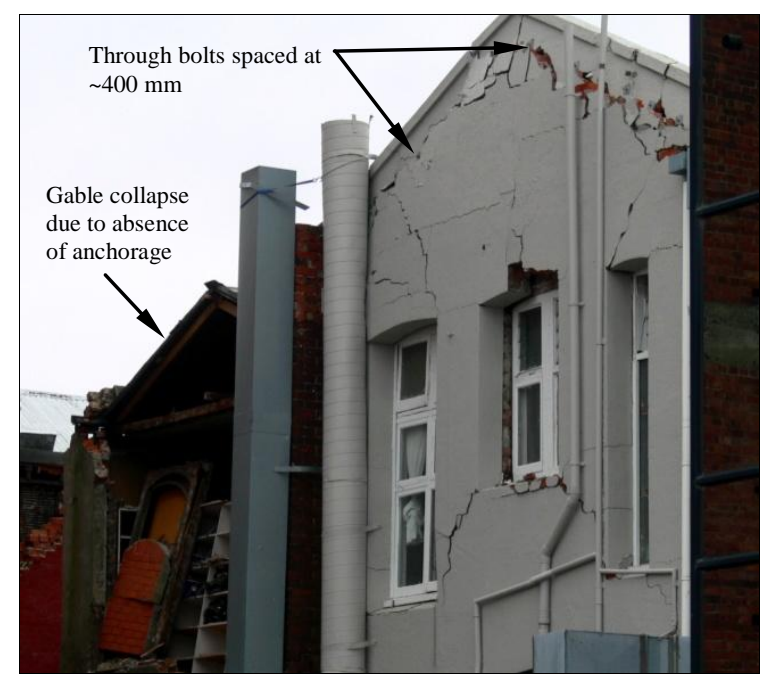

Figure 27: Failure of the gable due to low shear strength of masonry, despite sufficient anchorage.

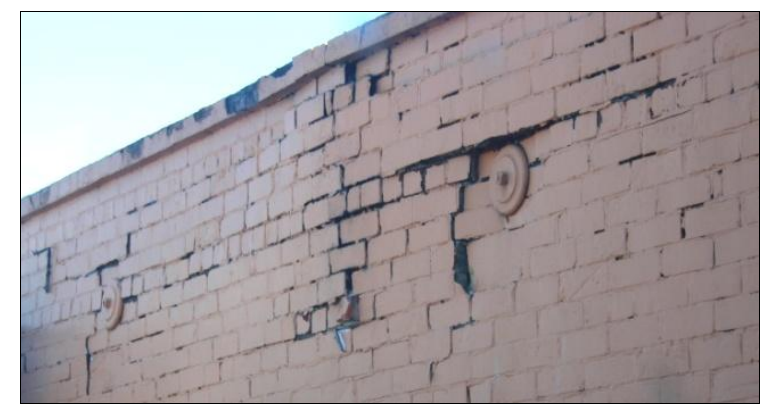

Figure 28: Wide spacing of anchors resulting in horizontal bending failure of masonry.

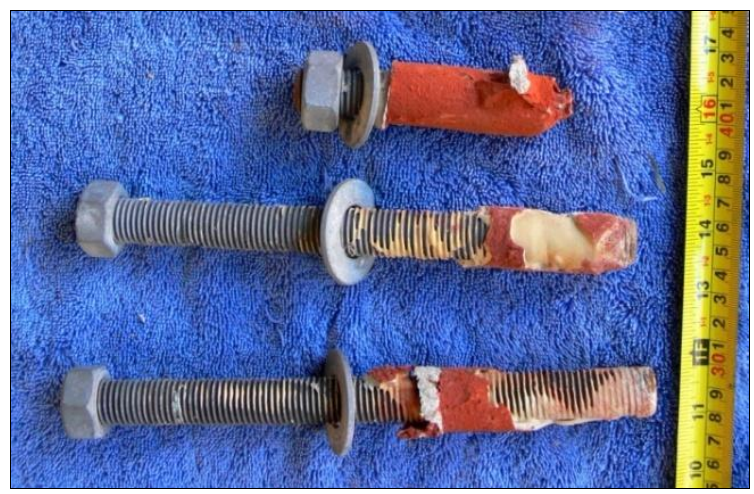

Figure 29: Recovered adhesive anchors that performed inadequately.

In-Field Testing of Adhesive Anchor Connections in Existing Clay Brick Masonry Walls

A collaborative international study was established between researchers at the University of Auckland (NZ) and the University of Minnesota (USA), partly funded by a NSFRAPID grant, and a research team was deployed to Christchurch during the months of July and August 2011 to conduct the in-field tests in order to obtain accurate data on the pullout strength of adhesive type anchors in existing clay brick masonry walls.

Given the difficulties associated with testing existing anchors, the research team opted to test new anchors installed in the exterior façade of exterior walls in existing brick buildings in Christchurch. To test existing anchors would have required the research team to work inside damaged buildings during subsequent aftershocks, to disconnect the existing anchors from roof or floor diaphragms to enable loading of the anchors using the testing equipment, and require temporary support to the disconnected wall and diaphragm during the test. Specific objectives of the field test program included the identification of failure modes of adhesive anchors in existing masonry and determination of the influence of the following variables on anchor load-displacement response: type of adhesive, the strength of the masonry materials (brick and mortar), anchor embedment depth, anchor diameter, and use of metal foil sleeve. In addition, the comparative performance of bent anchors (installed at an angle of minimum $22.5^{\circ}$ to the perpendicular projection from the wall surface) and anchors positioned horizontally was investigated, as well as the performance of through-bolt anchors with end plate connections. Table 1 lists the range of values for the selected variables.

Table 1: Range of values for test parameters in adhesive anchor tests.

\begin{tabular}{ll}
\hline Parameter & Range of Values \\
\hline Adhesive type & $\begin{array}{l}3 \text { epoxies and 1 cementitious } \\
\text { grout }\end{array}$ \\
Masonry material strength & $\begin{array}{l}\text { Very weak to intermediate } \\
\text { strength }\end{array}$ \\
Anchor embedment depth & $100,200,300,400(\mathrm{~mm})$ \\
Anchor diameter & $12,16(\mathrm{~mm})$ \\
Metal foil sleeve & Yes, No \\
& $\begin{array}{l}\text { Horizontal and 22.5 } \\
\text { perpendicular projection from }\end{array}$ \\
Orientation of anchor & wall \\
\hline
\end{tabular}

The field test program was conducted on three buildings located in the Wards Brewery Historic Area, nestled between Fitzgerald Avenue, Kilmore Street and Chester Street East. The buildings included the original malt house (c. 1881), a malt lot storage building (c. 1910), and one of the barrel 
storage buildings (c. 1920). All three buildings suffered significant damage during the 2010/2011 earthquakes, and at the time of the field test program they were scheduled for demolition. An indication of the relative strength of the masonry was established based on the building age, visual condition, perceived resistance to drilling and saw cutting, as well as results from in-situ bed joint shear tests. Fifteen bed joint shear tests were conducted in the field, and brick units and mortar samples were extracted and sent to the laboratory for testing.

A total of 170 anchors were installed and tested with the test set-up and loading procedure used to satisfy the New Zealand (AS/NZS 1170.0 [9]) and US (ASTM A488 [10]) standards, with a typical test arrangement illustrated in

Figure 30. The tests used a steel load frame, a manual pump, a loading jack, a load cell, and two displacement transducers (see Figure 31) to evaluate effectiveness of various adhesive anchors. The anchors were mostly DIN 975 class 4.8 steel, with a few anchors cut from DIN 975 grade 8.8 (highstrength) steel. For each combination of test parameters, 5 anchors were installed and tested. Applied tensile force and the corresponding displacement/slip were recorded using a digital data acquisition system. Peak pressure was also recorded manually, and photographs (before and after testing) were taken of all anchors.

Some preliminary observations of the field test program are:

- $\quad$ Failure modes included pullout of the anchors (especially in weaker masonry and shorter embedment depths), masonry breakout/anchor pullout (where the leading brick, or part of it, is pulled out with the anchor as shown in Figure 32), and anchor yielding (and fracture in some cases);

- Failures approximating the ideal breakout failure, in which rupture occurs in a roughly conical masonry failure surface, were not observed in any of the tests;

- The quality and strength of the masonry was found to be an important variable, as well as the strength of the adhesive, the size of the anchor, and the embedment depth;

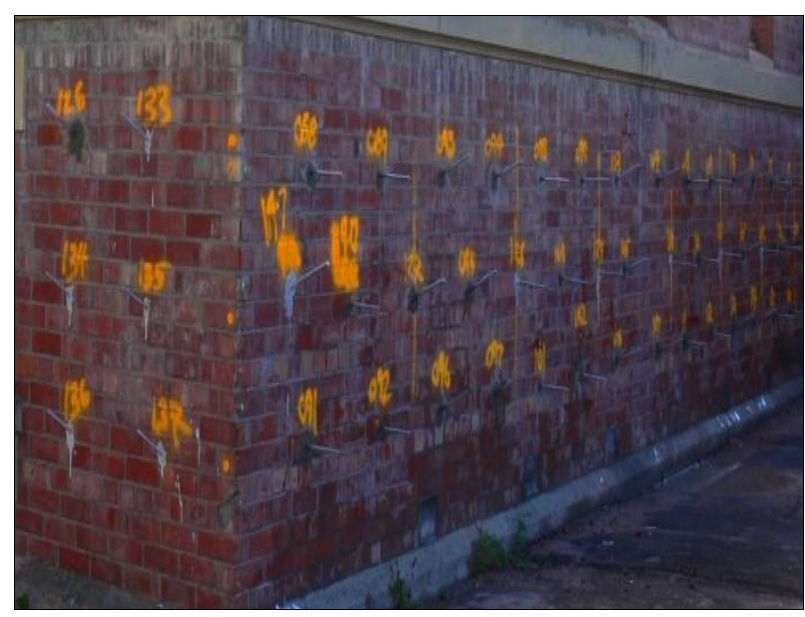

Figure 30: Typical test specimen arrangement.

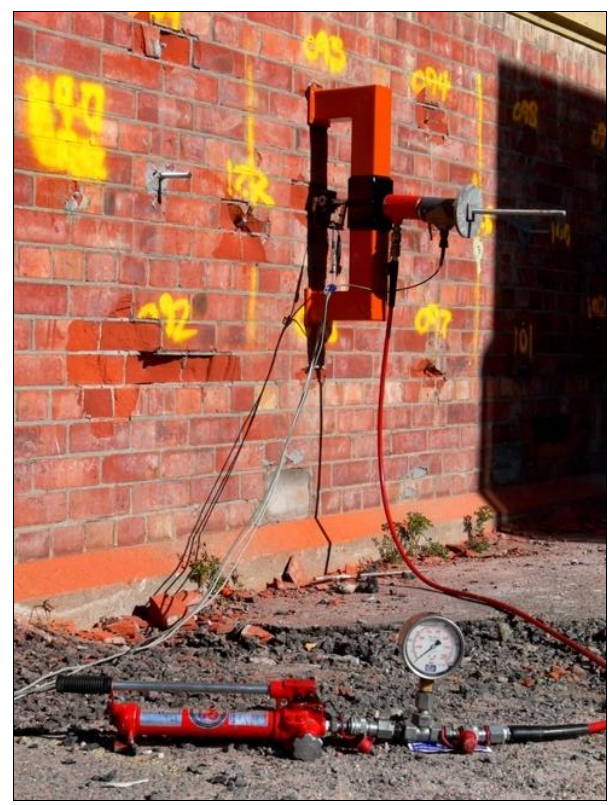

Figure 31: Typical test set-up used for pullout anchor testing.

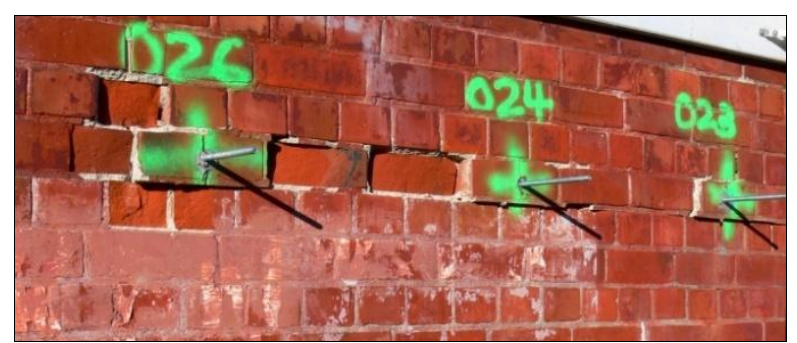

Figure 32: Typical masonry pullout type failure observed.

\section{Performance of Temporary Shoring}

For URM buildings damaged in the September 2010 earthquake, temporary shoring was commonly used to prevent further out-of-plane wall damage or collapses. Hence the performance of temporary shoring was assessed following the major aftershocks. Figure 33 and Figure 34 shows postSeptember 2010 shoring that assisted in preventing collapse of URM buildings in February 2011.

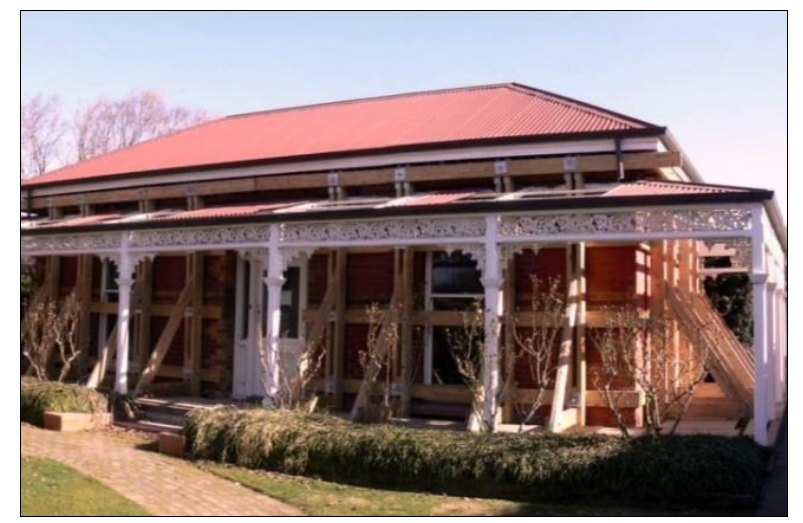

Figure 33: Extensive timber temporary shoring of a residential URM building following $4^{\text {th }}$ Sept earthquake. 


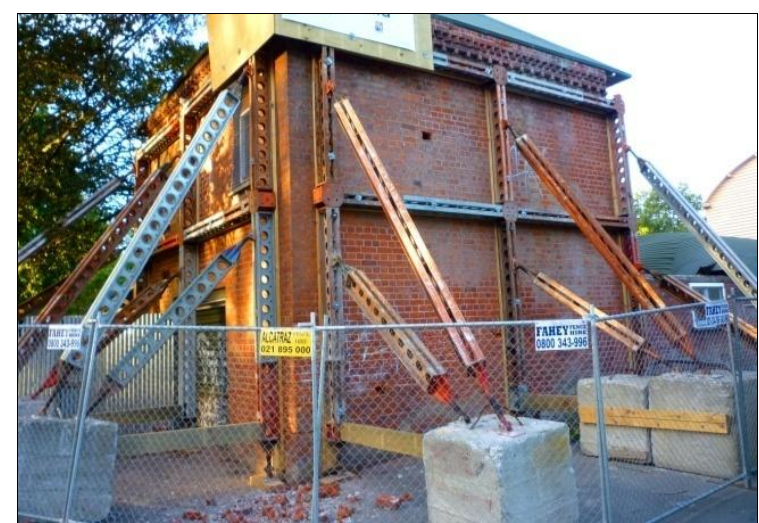

Figure 34: Extensive steel temporary shoring of a URM building following the $4^{\text {th }}$ Sept earthquake.

\section{UNREINFORCED STONE MASONRY BUILDINGS}

Damage assessment inspections undertaken in April and May 2011 identified 90 unreinforced stone masonry buildings in Christchurch, a large number of which are included on the Historic Places Trust register of heritage buildings. The distribution of the inspected stone masonry buildings is shown in Figure 35.

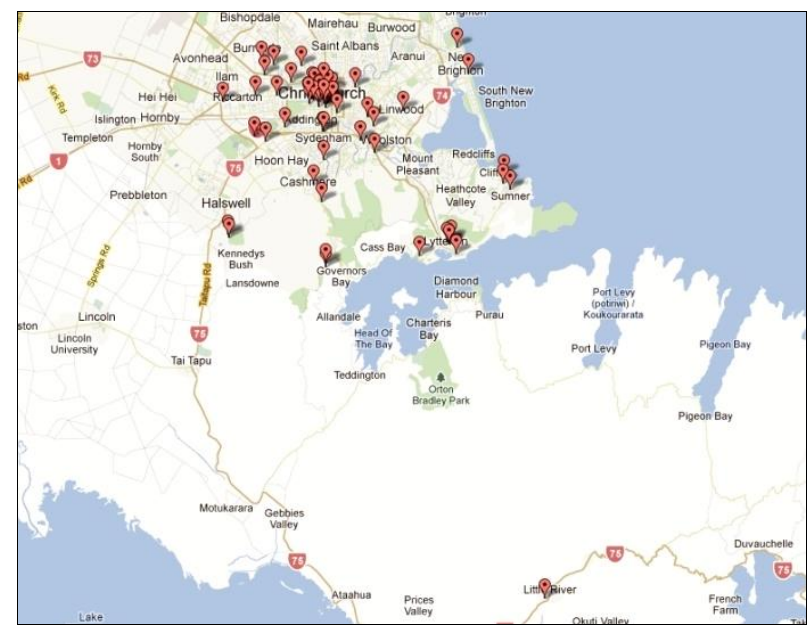

Figure 35: Location of inspected unreinforced stone masonry buildings.

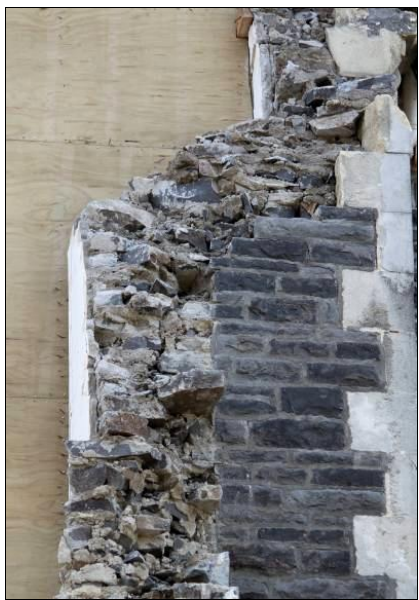

(a) Cranmer Court - 3 leaves with rubble fill

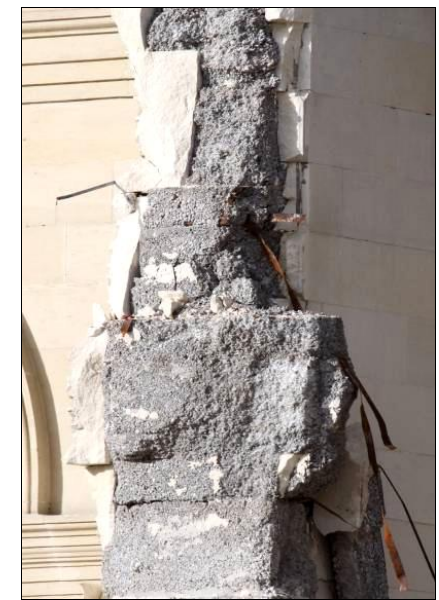

(b) Cathedral of the Blessed Sacrament - Oamaru stone with poured concrete
Unreinforced stone masonry buildings in Christchurch tend to have similar characteristics, in terms of both architectural features and construction details. This observation derives primarily from the fact that most of these structures were built over a comparatively short time period and were designed by the same architects or architectural firms. The vast majority of these structures, and in particular those constructed in the Gothic Revival style, are characterised by structural peripheral masonry walls that may be connected, depending on the size of the building, to an internal frame structure constituted of cast iron or steel columns and timber beams, or to internal masonry walls that support flexible timber floor diaphragms and timber roof trusses. However, there are a few commercial buildings in the Christchurch CBD that are characterised by slender stone masonry piers in the front façade, with the other perimeter walls constructed of multiple leaves of clay brick. These buildings are typically two or three stories in height, with two storey buildings being most common, and may be either standalone or row type buildings (see [4] for further details of URM building typology). The wall sections can be of different types:

- Three leaf masonry walls, with dressed or undressed basalt or lava flow stone units on the outer leaves while the internal core consists of rubble masonry fill (see Figure 36(a));

- Three leaf masonry walls, with the outer layers in Oamaru sandstone and a poured concrete core, such as that in the Catholic Cathedral of the Blessed Sacrament (see Figure 36(b));

- Two leaf walls, with the front façade layer constructed in dressed stone, typically being either dressed basalt or bluestone blocks, or undressed lava flow units, and the back leaf being one or two layers of clay bricks, usually with a common bond pattern, with the possible presence of a cavity or poured concrete between the inner and outer leaves (see Figure 36(c)). 


\section{Damage Mechanisms in Stone Masonry Buildings}

\section{Out-of-plane failure mechanism}

As expected for buildings with architectural features typical of the Gothic Revival style (long span façades, flexible floor diaphragms and weak connections between walls), partial or global overturning or instability of the façades was reported for most of the structures inspected, with damage ranging from moderate to severe and in some cases reaching collapse. Most buildings with out-of-plane failures appeared to have poor connections between the walls at their corners, leading to return wall separation and subsequent out-of-plane failure of entire walls.

Many of the stone masonry buildings that were constructed in the Gothic Revival style sustained damage to their gable ends, with many observed cases of complete collapse of the gable. The absence of significant gravity loads and inadequate connection between the gable and roof trusses were primary contributing factors to this gable end failure mode, along with high accelerations experienced at the top levels of the structure.

\section{In-plane response of walls}

As outlined previously, the $22^{\text {nd }}$ February 2011 earthquake appeared to have predominant shaking in the east-west direction. This observation is further supported by in-plane wall damage in the east-west running walls (see Figure 37) in conjunction with overturning of façades oriented in the orthogonal direction.

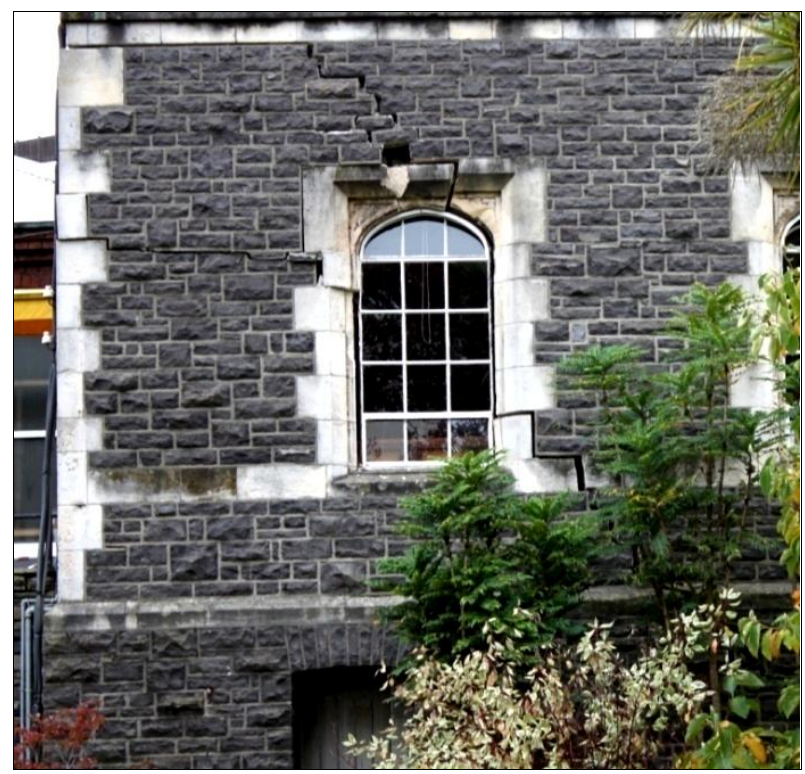

Figure 37: Canterbury Provincial Chambers - diagonal crack through entire south façade of the east annex.

\section{Damage due to geometric irregularities}

Damage that was attributable to plan irregularity was frequently observed, particularly for stone churches, due to the interaction between adjacent structural elements at the intersections between walls. In most churches where the bell tower or low annexes are connected to the nave, damage developed at the intersection of the different structures. A distinct example of damage due to plan irregularity in association with differential foundation settlement was observed at the former Old Boys' High building in the Arts Centre.

\section{Diaphragm and roof seismic response}

Both adequate and inadequate securing of walls and diaphragms using wall-diaphragm anchors was observed. In some cases anchors were either absent or were spaced too far apart to prevent bed joint shear failure of the masonry at the location of the anchorage. In those cases where anchors had been seismically designed, or anchors were sufficiently closely spaced to resist lateral loads, the overturning of gables and other portions of walls was prevented.

Two cases are presented to show the different behaviour induced by the presence and effectiveness of anchorage. Figure 38 shows the damage resulting from overturning of the gable of the main façade of the former Trinity Church in the Christchurch CBD, where anchors were insufficient in size and spacing to secure the wall in place. Figure 39 shows an example of successful wall-to-roof anchorage in an Arts Centre building.

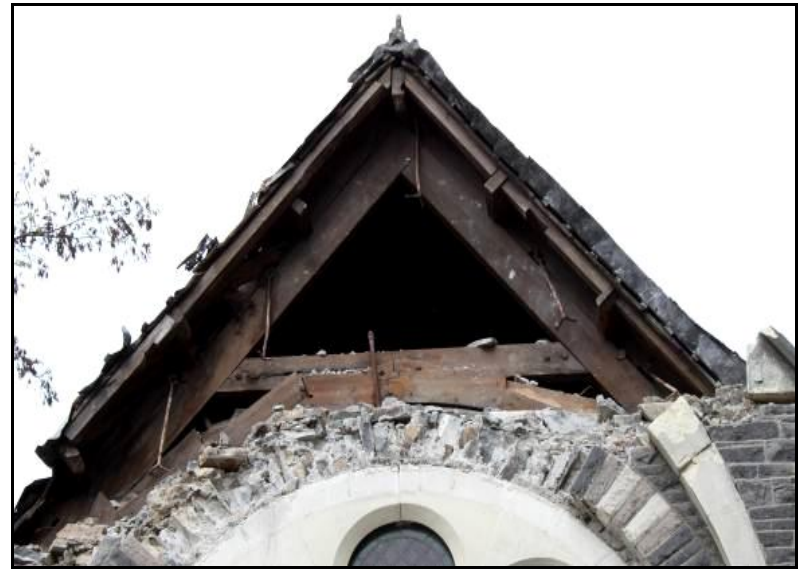

Figure 38: Former Trinity Church, showing details of gable end out-of-plane wall failure.

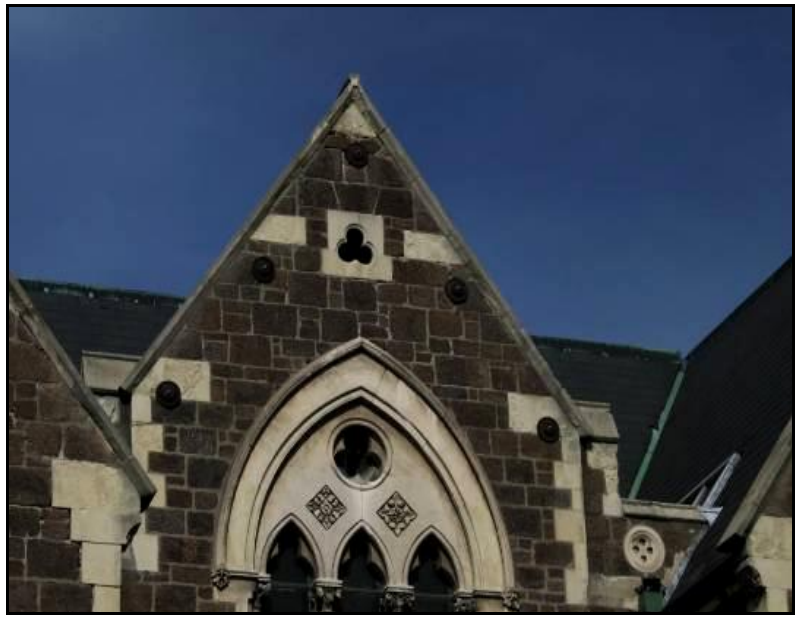

Figure 39: The Christchurch Arts Centre, showing successful use of wall-diaphragm anchorages.

Damage induced by poor quality of construction materials The quality of construction materials played a key role in the response of stone URM buildings. As previously described, one of the typical features of unreinforced stone masonry buildings in Christchurch is the different types of stone and mortar quality present in structures built with three-leaf walls. The use of soft limestone, such as Oamaru stone or the red tuff extracted in the Banks Peninsula, in conjunction with the use of low strength lime mortar, often led to poor earthquake response. Examples of such behaviour include the Holy Trinity Church in Lyttelton, as illustrated in Figure 40. 


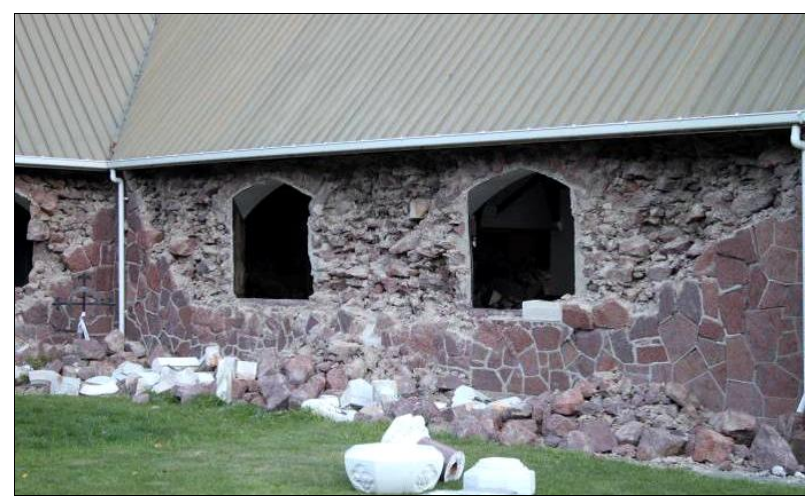

Figure 40: Lyttelton Holy Trinity Church, showing damage induced by movement of the roof.

\section{RETROFIT INTERVENTIONS FOR STONE MASONRY BUILDINGS}

\section{General Principles and Suggested Procedures}

The poor seismic performance of unreinforced stone masonry buildings in Christchurch is a reminder of the necessity to seismically retrofit heritage buildings in an earthquake prone country such as New Zealand. Suggestions for appropriate strengthening principles and techniques should be gathered from the experiences accumulated by researchers and practitioners in other seismic areas of the world which have stone masonry buildings with similar characteristics.

Retrofit interventions should improve the performance of the structure as a complete entity, by eliminating or significantly reducing structural deficiencies associated with design and execution errors, and deterioration and damage. Issues relating to both the vulnerability and the suitability of retrofit interventions should be accounted for, with particularly attention given to the effects of variations in stiffness between elements and the stiffness changes associated with various retrofit techniques. Strengthening interventions should enhance the global behaviour of the structure and also the performance of isolated structural elements, and should seek to keep loads well distributed to avoid elevated stress levels. Where necessary, interventions should address the possibility of rocking and over-turning instability, and should support a clearly defined load path through use of in-plane shear walls. Furthermore, repair and retrofitting techniques should respect the original structure in order to avoid incompatibility of both materials and structural form.

Interventions should be regular and uniformly distributed on the structure. The execution of strengthening interventions on isolated parts of the building must be accurately evaluated (with the aim of reducing or eliminating vulnerable elements and structural irregularity) and justified by calculating the effect in terms of the modified stiffness distribution.

Particular attention should be given to correct implementation of the intervention strategy, as poor execution can cause deterioration of masonry characteristics or worsening of the global behaviour of the building, reducing the global ductility capacity. Some examples of studies into the performance of retrofit interventions are described in Binda et al. [11], Vintzileou et al. [12], Valluzzi et al. [13], Valluzzi [14] and Augenti \& Parisi [15]. Different types of interventions are suggested in well known Building Codes and Guidelines, such as EC 8 [16], NTC [17], ASCE [18] or FEMA 547 [19]. These intervention types can be categorised as follows:

- Improvement of floor to wall connections by the introduction of anchoring ties, reinforcing ring beams and floor-to-wall connections [19];
- Improvement of the behaviour of arches and vaults, through the installation of ties and extrados metallic elements, or application of composite materials;

- Reduction of excessive floor deformability (in-plane and flexural stiffening with dry techniques, extrados intervention with boarding, steel or Fibre Reinforced Polymer (FRP) straps; bracing or other interventions at the intrados);

- Improvement of the roof or floor structures and the load transfer fixings into the supporting walls;

- Strengthening of masonry walls, either by local rebuilding of walls, by grout injections, application of anti-expulsive tie-rods (such as helical wall ties and anchoring systems), repointing of the mortar joints (reinforced repointing [20]), jacketing, insertion of artificial through-stones, application of transverse tying [21];

- Improvement of pillars and columns, through measures such as circumferential hoops and reinforced injections;

- Improvement of connections to non-structural elements.

\section{REINFORCED CONCRETE MASONRY}

External evaluations of 471 concrete masonry buildings within the Christchurch CBD were performed following the $22^{\text {nd }}$ February 2011 earthquake, with the location of these buildings shown in Figure 41. The inspected buildings were classified as one of three construction types: RCM solid wall construction, RCM cavity wall construction, or reinforced concrete (RC) frame with concrete masonry infill. Whilst the observed damage to concrete masonry infill construction was recorded, the reinforced concrete frame was considered to be the principal structural system. Concrete masonry cavity wall construction typically consisted of a $100 \mathrm{~mm}$ thick outer leaf of concrete masonry block with an inner structural leaf of RCM. Details of the $342 \mathrm{RCM}$ buildings having solid wall and cavity wall construction are summarised below.

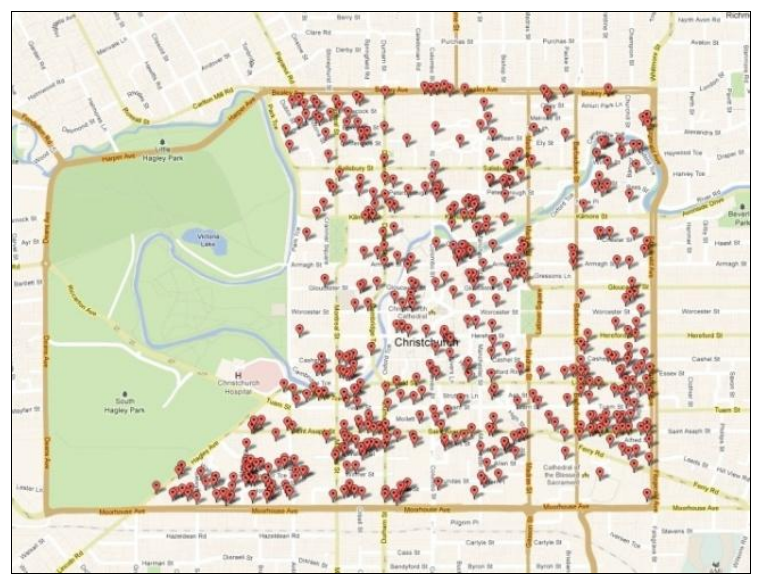

Figure 41: Location of inspected RCM buildings.

The majority ( $83 \%$ ) of RCM buildings had little or no damage following the earthquake, as shown in Figure 42(a). Nevertheless, exceptions to this good behaviour were observed. The concrete masonry buildings damaged in the earthquake exhibited diagonal in-plane shear cracking as the primary failure mode, as shown in Figure 42(b). Diagonal inplane shear cracking included both step pattern cracking along the head and bed mortar joints, and diagonal cracking through masonry blocks. Vertical cracking of the block was also commonly observed, followed less frequently by horizontal cracking along bed joints and spalling of the block, typically due to face shell blowouts, as shown in Figure 42(b). In Figure 42 (b) the 'other' category includes failures due to 
ground settlement, out-of-plane failures and full collapse of simple elements.

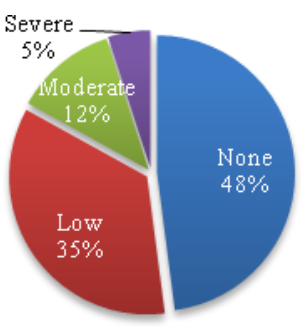

(a) Damage Level of $R C M$

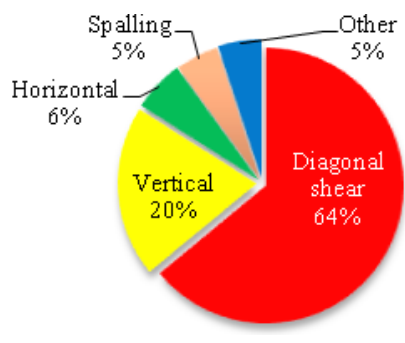

(b) Failure Types of RCM
Figure 42: RCM inspected buildings.

Severe diagonal cracking of RCM shear walls in a multistorey commercial building in the central CBD was observed, as shown in Figure 43. This building had a glass store front with RCM shear walls in the N-S and E-W directions, as well as an RCM elevator shaft. The reinforcement had insufficient cover in places, causing face shell spalling of some concrete masonry units.

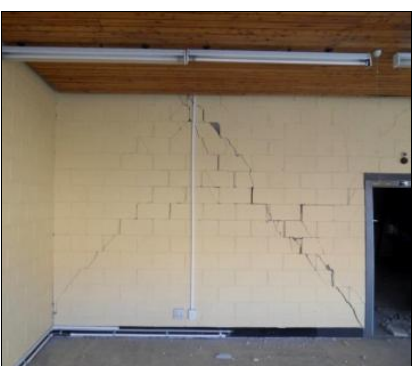

(a) Severe diagonal shear cracking of RCM shear walls

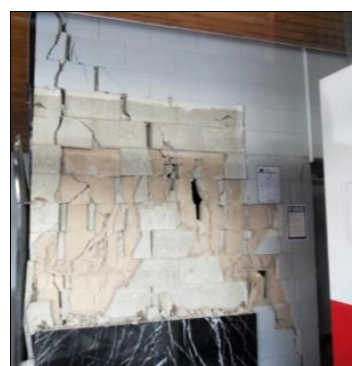

(b) Close-up of diagonal shear cracking
Figure 43: Examples of diagonal shear cracking.

Similar diagonal shear cracking was observed in a five-storey apartment complex having RCM cavity wall construction, as shown in Figure 44. The diagonal crack pattern of the $100 \mathrm{~mm}$ external leaf was mirrored, although less extensively, on the RCM internal leaf. This form of cavity construction was somewhat unconventional as the external leaf was also reinforced, although provided insufficient cover to the reinforcement due to the narrow width of the concrete masonry units (CMUs) used in the exterior leaf. Because of the small void size in the exterior CMUs, in several locations grout was observed to be discontinuous or honeycombed, providing inadequate bond to the reinforcement. The damage to this building was so severe that the building was scheduled to be demolished. Similarly, of the severely damaged RCM buildings where the grout and reinforcement were visible, approximately fifty per cent had improper fill or incorrect reinforcement placement.

More details of common construction deficiencies are shown in Figure 45. Figure 45(a) shows a bond beam block in a collapsed garage wall that was neither filled nor reinforced. Figure 45(b) shows a collapsed RCM wall addition to a URM building, in which the grout was not continuous even at the top of the wall, leaving the reinforcement exposed. These observations indicate that inadequate inspection procedures exited at the time of construction. Observed damage to RCM buildings suggests that design and detailing of piers around openings also requires further attention. In buildings that appeared to have adequate grouting and detailing, severe failures mainly occurred in these elements.

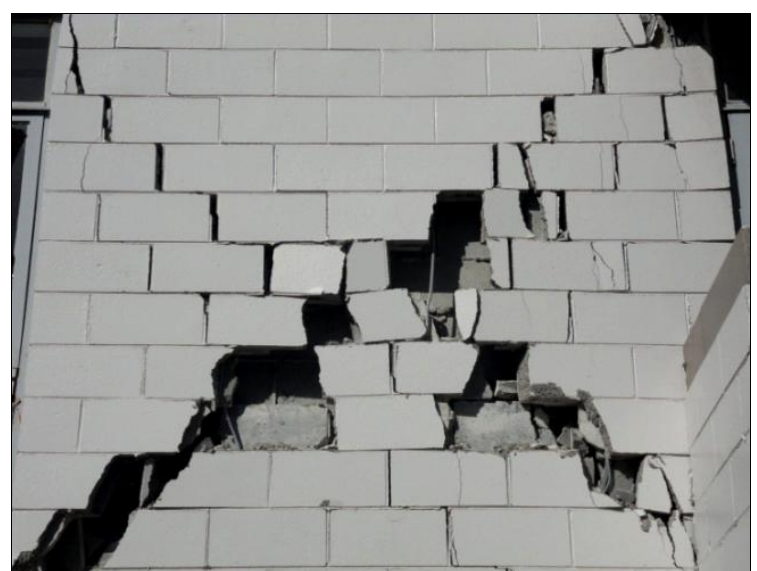

Figure 44: Severe diagonal cracking of RCM cavity shear wall.

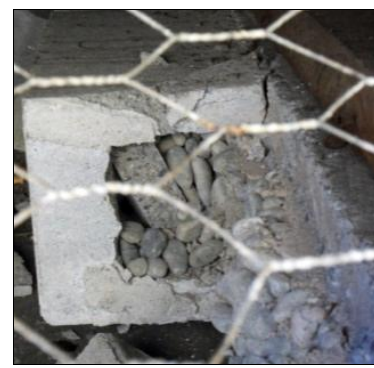

(a) Poor cell grouting

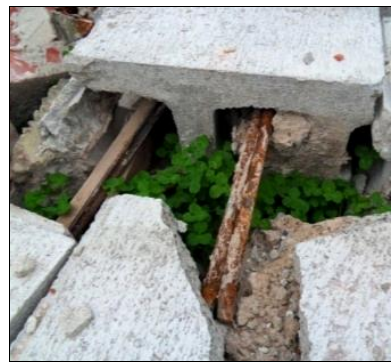

(b) Ungrouted masonry cells
Figure 45: Examples of RCM construction deficiencies.

Several instances of structural damage in other inspected RCM buildings suggest inadequate reinforcement detailing. Various cases of lap-splices at plastic hinge locations showed buckling of reinforcement bars. A large number of damaged RCM walls showed vertical reinforcement near the ends of the wall to be unconfined by horizontal reinforcement (see Figure 46(b)) as the horizontal reinforcement terminated prior to the final vertical bar.

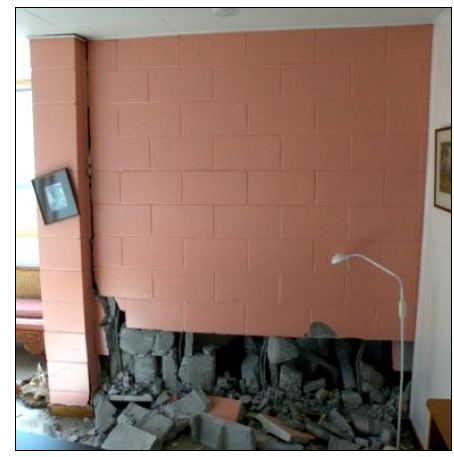

(a) Flexural failure of RCM wall due to spalling and crushing of grout

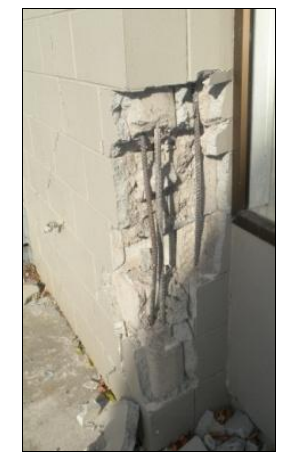

(b) Buckling of unsupported lapspliced vertical reinforcement
Figure 46: Damage to RCM shear walls following the February 2011 earthquake.

RCM buildings with vertical cracking suffered only minor damage. Several commercial buildings near the centre of the CBD had RCM shear walls as side walls, with a glass store frontage. These buildings frequently had vertical cracking at the front ends of the RCM walls. Damage due to horizontal cracking was again minor and generally occurred at either the first course above or below a floor height. Finally, minor diagonal cracking near openings was the most commonly observed damage in RCM buildings. 


\section{Modelling of Case Study Buildings}

Following the $22^{\text {nd }}$ February 2011 earthquake, many cases of existing midrise buildings of RCM construction achieved life safety performance for a level of shaking beyond that specified in the current New Zealand Loadings Standard [9]. Cases of severe structural damage to RCM buildings were found in the vicinity of the CBD. As reported above, structural damage to these buildings has been documented and is currently being studied to establish the lessons which can be learned from this earthquake and how to incorporate these lessons into future RCM design and construction.

Among the cases being studied is a six storey RCM building named Rollerston Courts that nearly collapsed and was subsequently demolished. The RCM building consisted of a ground floor for storage and parking that incorporated $\mathrm{RC}$ walls, and apartments above having RCM shear walls, and an RCM lift shaft. The interior RCM structural walls showed damage due to flexure in the east-west direction, with face shell spalling and grout crushing at the lower two courses in the second storey, and diagonal cracking. These walls were found to exhibit a flange effect due to the adjacent orthogonal walls. Currently, an analytical model is being developed to investigate the structural response of this building.

Another case study building is the New Zealand College of Early Education, which was a four storey building with a lateral system of RC shear wall lift shaft, RCM perimeter walls, a gravity system consisting of RC circular columns, $\mathrm{RCM}$ wall columns and precast RC beams. The damage pattern and the offset location of the RC shear wall core suggests a torsionally sensitive response. All gravity columns in the building showed inelastic flexural damage, with concrete cover spalling at the top of RC columns in all stories and severe toe crushing and vertical splitting in RCM wall columns. However, the external RCM wall sustained only minimal damage. The $\mathrm{RC}$ shear wall core presented flexural yielding cracks near the ground level. The mortar crack patterns in the RCM shear walls adjacent to the RC shear wall showed signs of yielding of the vertical reinforcement across the height of the ground floor (see Figure 47). Two other torsionally sensitive RCM buildings are also being studied.

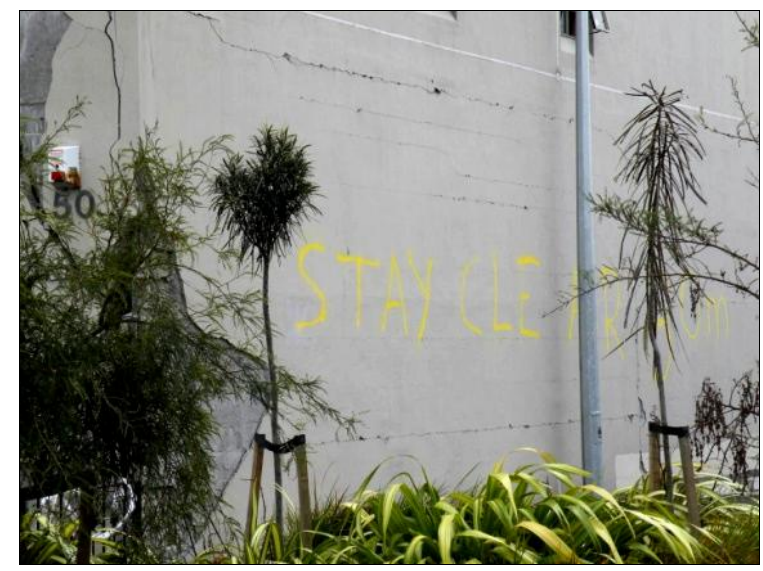

Figure 47: Bed joint cracks indicating yielding of reinforcement across the height of the first floor.

\section{CHURCHES}

In the 1840 's the rapidly increasing Canterbury population from European settlement substantially increased the demand for residential and community buildings. The first churches built in Canterbury were mainly of timber frame construction, due to the simplicity of construction and the availability of the material. As the financial prosperity of the area developed, stone and clay brick began to be used for the construction of important and public buildings including churches. Consequently timber, stone and clay brick masonry are the most common construction materials used for church construction in the Canterbury region. Examples of churches constructed using these materials are shown in Figure 48. Although less common, a number of churches were constructed during the first quarter of the $20^{\text {th }}$ century using reinforced concrete, and combinations of the above materials were also used.

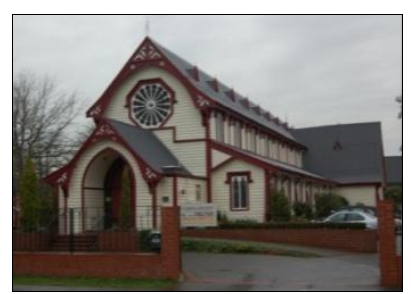

(a) Timber church of St Andrews, Merivale, 1857

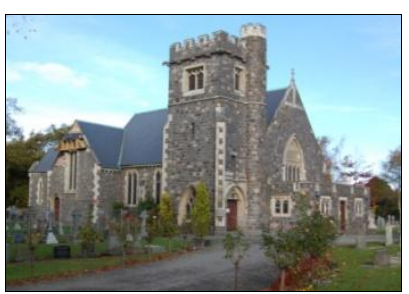

(b) Stone church of St Peters, Upper Riccarton, 1876

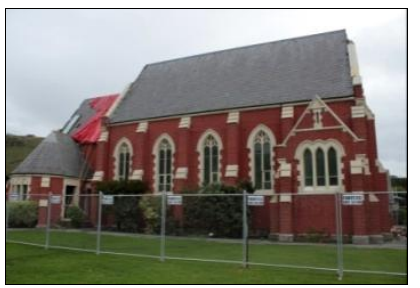

(c) Clay brick church of Our Lady Star of the Sea, Sumner, 1912

\section{Figure 48: Representative churches found in the Canterbury region.}

Beginning in May 2011, earthquake damage of 112 churches in the Canterbury region was inspected and assessed by a team of researchers. The distribution of inspected churches in the Canterbury region is shown in Figure 49. The inspection procedure included recording the Civil Defence Placard information assigned to churches during the immediate postearthquake safety evaluation, a detailed visual inspection of the buildings' exterior, and in cases where permissible and safe a detailed inspection of the buildings' interior, with detailed photographic documentation of any damage.

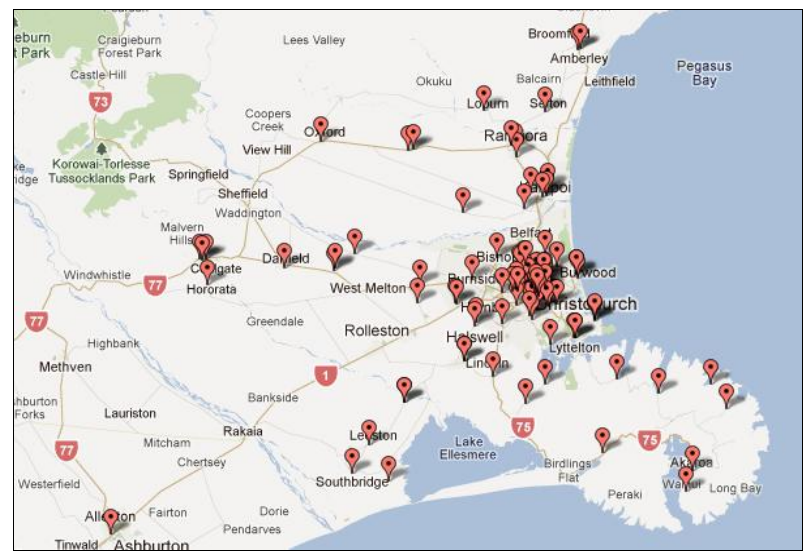

Figure 49: Location of inspected churches.

\section{Statistical Analysis}

Figure 50(a) shows that the assessed churches can be classified into three main categories according to the original construction material: stone (28\%), brick (19\%), wood (42\%), and other $(11 \%)$. Given the potentially different seismic behaviour of the three construction types, a general analysis of the placard classification (shown in Figure 50(b)) as undertaken by the NZ Fire Service, Urban Search and Rescue and volunteer engineers is potentially misleading. 


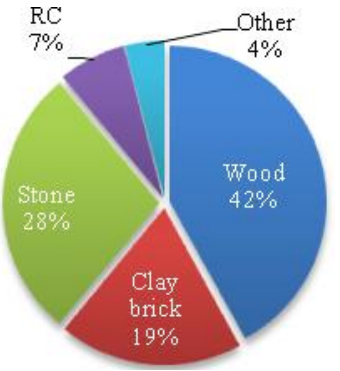

(a) Church construction material breakdown (b) Overall church placard classification

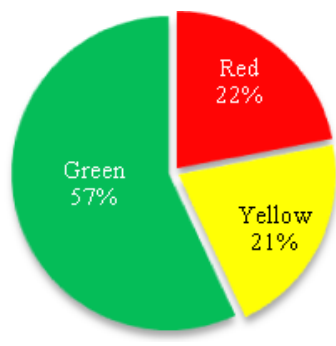

Figure 50: Construction type and damage for inspected churches.

Figure 51(b) shows the distribution of the placard classifications for the stone masonry churches, with over half (52\%) assigned a red placard. Also, the percentage of green placards received for the stone masonry churches was the smallest of the three church classifications.

Clay brick churches, as shown in Figure 51(a), had better seismic performance than did stone masonry churches, with red placards assigned to $38 \%$ of the churches and yellow placards assigned to $43 \%$ of the total. The percentage of red placards for this construction type is smaller than the percentage for the stone masonry churches. However, the sum of red and yellow placards is similar for the two construction types and was over $80 \%$.

Timber churches had the best overall performance, with none of the assessed churches showing any type of structural damage and, as can be seen in Figure 51(c), 94\% were assigned green placards. The only damage recorded to timber churches was to non-structural elements. Internal plaster damage, as shown in Figure 52, is an example of damage that might limit the use of a timber church and result in a yellow placard. All red placards assigned (2\%) were due to external causes (i.e. risk from a neighbouring building), where the churches were structurally undamaged.

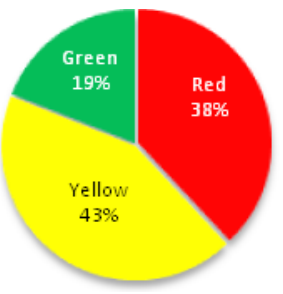

(a) Clay brick masonry churches

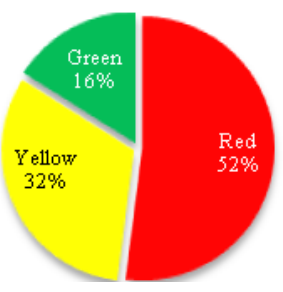

(b) Stone masonry churches

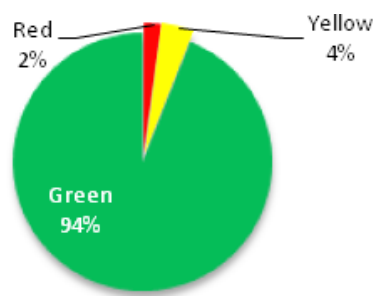

(c) Timber framed churches

Figure 51: Distribution of the placard classification for each construction type.

The inspected churches, irrespective of the construction material, followed a similar architectural style and consequently presented similar possible collapse mechanisms. Certain elements such as domes, vaults and chapels were infrequently present, just as bell towers and presbyteries were only found in a limited number of churches. Normally these elements present a higher seismic vulnerability. Given this finding, the dominant activated and most vulnerable collapse mechanisms for the stone and clay brick masonry churches were shear cracks along the longitudinal walls as shown in Figure 53(a) and (b), and the overturning of façades and apses as shown in Figure 53(c) and (d).

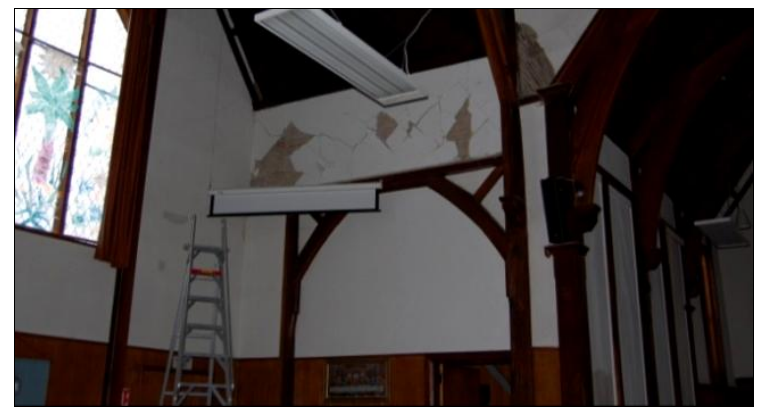

Figure 52: Damage to the internal plaster of St. Paul's Anglican Church, Harewood Road.

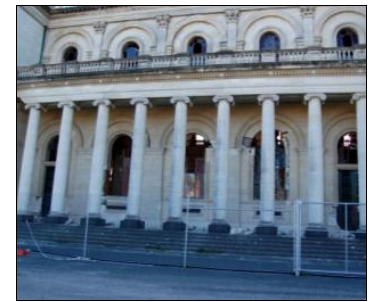

(a) Cathedral of the Blessed Sacrament, shear mechanism on the longitudinal walls

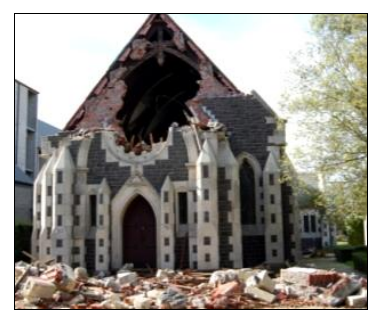

(c) Rose Historic Chapel, overturning of the top of the whole façade

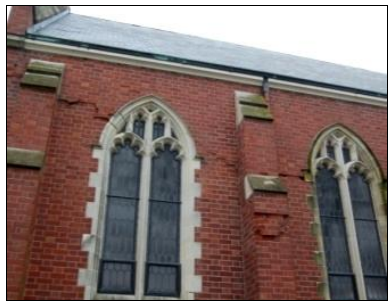

(b) Nazareth's House Church, shear mechanism on the longitudinal walls

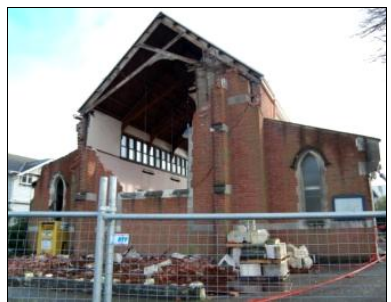

(d) Christchurch Chinese Methodist Church overturning of the top of the whole façade

Figure 53: Most commonly observed collapse mechanisms in churches.

Timber framed churches share the architectural pattern of stone and clay brick masonry churches, but the structural characteristics of these buildings do not lead to activation of the same collapse mechanisms. The lower structural mass decreases the generated inertial forces and the global response of the structure, which is characterised by integral response rather than deforming as a set of elements, contributed to the better seismic performance of the timber churches.

\section{RESIDENTIAL MASONRY VENEER}

Following the 2010/2011 Canterbury earthquakes a comprehensive literature review and detailed door to door assessments of residential masonry veneer dwellings were 
conducted in a variety of areas of Christchurch. Specifically, care was taken to include survey locations that had experienced different levels of earthquake shaking, in order to allow comparison between different system performances and different shaking intensities. Following the $4^{\text {th }}$ September 2010 Darfield earthquake little shaking damage was observed to residential masonry veneers and observed damage was instead due to foundation settlement, soil liquefaction and lateral spreading. However, it was noted that newer, lighter veneer systems appeared to perform better than older, heavier systems.

\section{Inspection Survey}

In total just under 1,100 residential dwellings were inspected throughout the wider Christchurch area (see Figure 54), of which $24 \%$ were constructed using the older nail-on veneer tie system (before 1996) and $76 \%$ were constructed using screw fixed ties to comply with the new 1996 standards revision (post-1996). 30\% of all inspected houses were of two storey construction. Of the inspected dwellings $27 \%$ had some evidence of liquefaction, ground settlement or lateral spreading. In areas where some form of liquefaction or lateral spreading had occurred, the cause of damage for $40 \%$ of the dwellings was attributed to ground movement only and $28 \%$ of dwellings had damage that was attributed to shaking damage only.

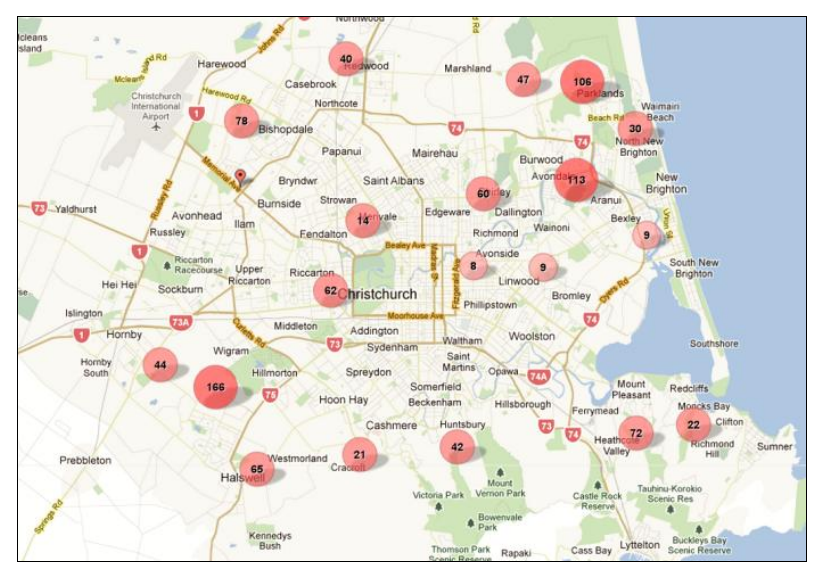

Figure 54: Location of inspected residential veneer dwellings.

Severe (example shown in Figure 55) and extreme damage to veneer dwellings was concentrated in the Port Hills and foothills suburbs (13\% of inspected dwellings) due to the proximity to the epicentre as well as typographical amplification of ground motions. It was also evident that the majority of cases of severe and moderate damage were concentrated close to the river banks (typically the residential 'Red Zone'), mainly due to substantial liquefaction and lateral spreading.

As expected, the level of damage increased with an increasing level of ground acceleration. It was evident that severe and extreme damage only occurred to veneers in areas of severe peak ground acceleration (PGA) $(0.62 \mathrm{~g}-1.3 \mathrm{~g})$ or extreme $(>1.3 \mathrm{~g})$ shaking. Of all inspected damaged dwellings, $60 \%$ sustained in-plane damage only, with dwellings constructed prior to 1996 being more likely to sustain out-of-plane damage in comparison to dwellings constructed after 1996. Of all the inspected dwellings which sustained some damage, $33 \%$ of these dwellings had problems with corner separation. From the survey it is evident that generally houses constructed since the 1990s tended to suffer lower levels of damage than those built earlier. It is evident that overall screw-fixed ties performed better, with the majority of the dwellings where this type of tie was used showing no visible or minor damage only.
It is apparent that damaged dwellings with nail-on ties featured more predominantly in the moderate to extreme damage categories, and it appears that wire ties performed the worst as a higher proportion of inspected dwellings that had wire type veneer ties sustained severe to extreme damage.

From the survey, it is evident that the use of Oamaru stone veneer (and solid veneer units in general) performed the worst, and a typical example of such performance is illustrated in Figure 56.

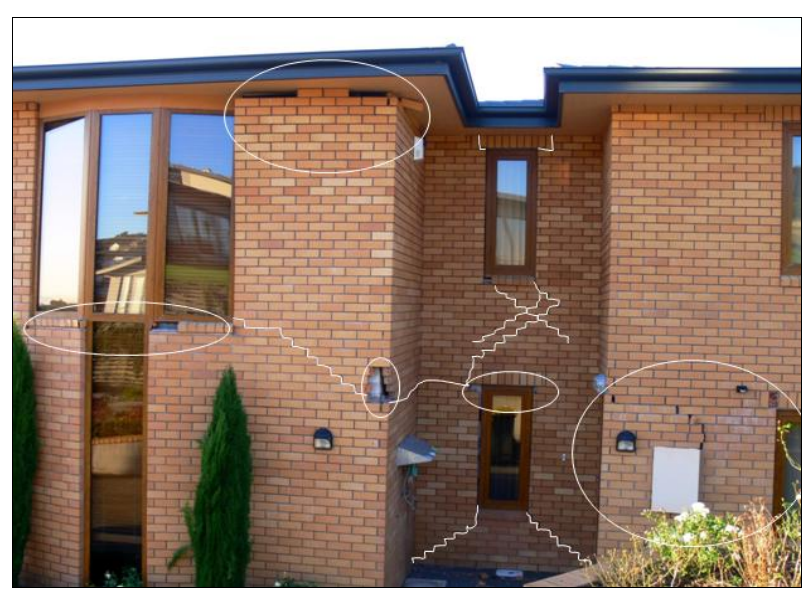

Figure 55: Example of severe veneer damage level.

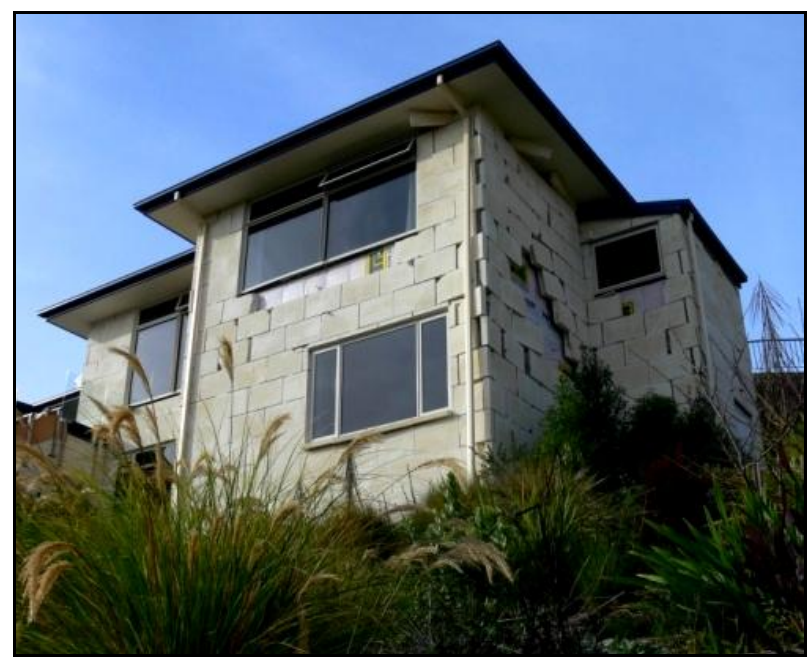

Figure 56: Poor performance of Oamaru stone veneer.

\section{CONCLUSIONS}

A brief summary of activities undertaken as part of Project Masonry was presented, detailing the observations that were made on the performance and the deficiencies that contributed to the damage to unreinforced clay brick masonry buildings, to unreinforced stone masonry buildings, to reinforced concrete masonry buildings, to churches in the Canterbury region, and to residential dwellings having external masonry veneer cladding.

It was concluded that when subjected to the higher forces generated by the earthquake on $22^{\text {nd }}$ February 2011, Christchurch's unreinforced masonry building stock sustained much greater and more widespread damage than in the $4^{\text {th }}$ September 2010 earthquake. The damage modes observed in September 2010 were again observed after February 2011, together with additional modes. Chimney, parapet and gable failures were again observed, along with out-of-plane failures. Primary types of out-of-plane wall failures that were observed were:

- Cantilever type out-of-plane failure with the entire top section of a wall or building façade collapsing; 
- One-way bending of the wall, which tended to occur in longer walls or walls without side supports;

- Two-way bending, which required support of at least one vertical edge of a wall.

Damage in the plane of URM walls was widely observed including:

- Diagonal shear cracking in piers, spandrels and walls;

- Shear sliding on mortar bed joints or between storeys;

- In-plane rocking and toe crushing of piers.

Ground deformations were also observed to contribute to building damage. Generally retrofit and temporary shoring techniques prevented entire building collapse.

Cavity construction was encountered in almost half of the URM buildings surveyed in Christchurch, with the remainder having solid interconnected multi-leaf walls.

Common types of seismic retrofits observed in Christchurch URM buildings were:

- Steel moment frames, which increased the lateral capacity of a building;

- Steel strong-backs, which helped prevent out-of-plane failure of URM walls;

- Application of shotcrete, which increased the in-plane and out-of-plane wall strength.

It was concluded that retrofits that generally performed well were:

- Well conceived designs which aimed to reduce torsional effects and tied the masonry together;

- Well connected steel strong backs and steel moment frames.

Field observations revealed numerous cases where anchor connections joining masonry walls or parapets with roof or floor diaphragms appeared to have failed prematurely, particularly for the case of adhesive anchors. In many cases these failures were attributed to the low shear strength of masonry, wide anchorage spacing, insufficient embedment depth of anchors, and/or poor workmanship.

It was concluded that the successful performance of anchors does not necessarily prevent out-of-plane wall failure, as the potential for one or two way out-of-plane wall bending failure is not necessarily precluded.

A total of 170 adhesive anchors were installed and tested to identify the failure modes in existing masonry and to determine the influence on anchor load-displacement response for the following variables: type of adhesive, the strength of the masonry materials (brick and mortar), anchor embedment depth, anchor diameter, and use of metal foil sleeve.

Damage assessment of unreinforced stone masonry buildings in Christchurch was conducted in April and May 2011 and consequently the presented description of their seismic response is based on observations made at that time. Following the $13^{\text {th }}$ June 2011 earthquakes and successive aftershocks, the conditions of damaged heritage stone masonry buildings continued to deteriorate, with more cases of partial or complete collapse. Hence, the importance of earthquake strengthening New Zealand's heritage masonry architecture to preserve a key element of the nation's history continues to be emphasised.

Following the $22^{\text {nd }}$ February 2011 earthquake, many cases of existing midrise buildings of RCM construction achieved life safety performance for a level of shaking beyond that specified in the current New Zealand Loadings Standard. In the Christchurch CBD 342 RCM buildings (including RCM buildings having veneer construction) were inspected and evaluated. The majority of these buildings suffered little or no damage, and in the remainder shear failure was the predominant damage mode observed.

Cases of severe structural damage to RCM buildings were found in the vicinity of the CBD. Structural damage to these buildings has been documented and is currently being studied to establish the lessons which can be learned from this earthquake and how to incorporate these lessons into future RCM design and construction.

Beginning in May 2011, earthquake damage of 112 churches in the Canterbury region was inspected and assessed. The assessed churches were classified into three main categories according to the original construction material: stone (28\%), brick $(19 \%)$, wood $(42 \%)$ and other $(11 \%)$. Given the potentially different seismic behaviour of the three construction types, a general analysis of the placard classification undertaken by the NZ Fire Service, Urban Search and Rescue and volunteer engineers was presented.

In total just under 1,100 residential dwellings were inspected throughout the wider Christchurch area, of which $24 \%$ were constructed using the older nail-on veneer tie system (before 1996) and $76 \%$ were constructed using screw fixed ties to comply with the new 1996 standards revision (post-1996), and where $30 \%$ of all inspected houses were of two storey construction. Of the inspected dwellings $27 \%$ had some evidence of liquefaction, ground settlement or lateral spreading. In areas where some form of liquefaction or lateral spreading had occurred, the cause of damage for $40 \%$ of the dwellings was attributed to ground movement only and $28 \%$ of dwellings had damage that was attributed to shaking damage only.

Whilst it may be too late to save many of Christchurch's historic clay brick and stone URM buildings, lessons learnt from damage observations made during and after the Canterbury earthquake swarm of 2010/2011 and future detailed analysis of the collected data can be applied to masonry buildings throughout the rest of New Zealand, Australia, and around the world.

\section{ACKNOWLEDGMENTS}

The authors wish to thank the numerous professional structural engineers and building owners who have provided valuable data, opinions, expertise and their experiences. In particular: John Hare, Stuart Oliver and others from Holmes Consulting Group Ltd.; Paul Campbell, Will Parker and others from Opus International Consultants Ltd.; Win Clark, Cecil DelaRue, Fiona Wykes and others from the Civil Defence Heritage team; Hossein Derakhashan and others from Aurecon New Zealand Ltd.; Andrew Marriot and others from Marriot Consulting Engineers Ltd.; and URS Consulting Ltd.

The authors thank Ronald Lumantarna for conducting and providing mortar and clay brick compression strength results. EQ STRUC Ltd. is thanked for providing expertise and test equipment and Hilti (NZ) Ltd., Reids Construction Systems Ltd and Sika (NZ) Ltd. are thanked for proving materials in order to conduct in-field anchor pull-out tests.

Darryl and Alistair from the Civil Defence demolition team, Graceworks Demolition, Ward Demolition, Southern Demolition, Nikau Demolition, and other demolition companies are thanked for allowing site investigation and access for sample collection during demolition of damaged buildings. 
Stephanie German and Jazalyn Dukes from Georgia Institute of Technology, Benoit Rozier from Ecole Nationale des Travaux Publics de l'Etat in Lyon, France, Will Cyrier from Washington State University and Chaminda Konthesingha from the University of Newcastle are also thanked for their assistance and contributions.

The authors acknowledge the financial support for Project Masonry from the New Zealand Natural Hazards Research Platform. The testing of adhesive anchors was undertaken in conjunction with the RAPID grant CMMI-1138614 from the US National Science Foundation. The investigation of the performance of residential brick veneers was financially supported by Brickworks Building Products Australia.

\section{REFERENCES}

1. GeoNet. (2010). M 7.1, Darfield (Canterbury), September 4 2010. Retrieved on $12^{\text {th }}$ July 2011. Available from: http://www.geonet.org.nz/earthquake/historicearthquakes/top-nz/quake-13.html

2. GeoNet. (2011). Feb M 6.3, Christchurch, February 22 2011. Retrieved on $12^{\text {th }}$ July 2011 Available from: http://www.geonet.org.nz/earthquake/historicearthquakes/top-nz/quake-14.html

3. IPENZ. (2011). Christchurch Earthquake Fact Sheets. Retrieved on $12^{\text {th }} \quad$ July 2011 http://www.ipenz.org.nz/ipenz/forms/pdfs/ChChFactShee ts-Overview.pdf

4. Russell, A. P. \& Ingham, J. M. (2010). "Prevalence of New Zealand's Unreinforced Masonry Buildings", Bulletin of the New Zealand Society for Earthquake Engineering, Vol. 43, No. 3, pp. 182-201.

5. Dizhur, D., Ismail, N., Knox, C., Lumantarna, R. \& Ingham, J. (2010). "Performance of unreinforced and retrofitted masonry buildings during the 2010 Darfield earthquake", Bulletin of the New Zealand Society for Earthquake Engineering, Vol. 43 No. 4, pp. 321-339.

6. Ingham, J. \& Griffith, M. (2011). "Performance of unreinforced masonry buildings during the 2010 Darfield (Christchurch, NZ) earthquake", Australian Journal of Structural Engineering, Vol. 11, No. 3, pp. 207-224.

7. Canterbury Earthquake Recovery Authority (CERA) (2011). Demolition Lists. Retrieved on $26^{\text {th }}$ July 2011. Available from www.cera.govt.nz/demolitions/list

8. Dizhur, D., Ingham, J. \& Griffith, M. (2010). "The performance of unreinforced masonry chimneys in the 2010 Darfield Earthquake", NZSEE Clearing House. Retrieved on $12^{\text {th }}$ July 2011. Available from: http://db.nzsee.org.nz:8080/documents/10533/5332db9532f8-47ab-b1af-bfde01f6d9b3

9. SNZ (2002) "NZS 1170.0:2002 Structural design actions - New Zealand." Standards New Zealand.

10. ASTM. (2003). "Standard Test Methods for Strength of Anchors in Concrete and Masonry Elements" E488-96, ASTM International, Pennsylvania, United States.

11. Binda, L., Modena, C., Baronio, G. \& Gelmi, A. (1994). "Experimental qualification of injection admixtures used for repair and strengthening of stone masonry walls", $10^{\text {th }}$ Int. Brick/Block Masonry Conf., Calgary, Vol. 2, pp. 539-548.

12. Vintzileou, E. \& Tassios, T. P. (1995). "Three-leaf stone masonry strengthened by injecting cement grouts", Journal of Structural Engineering, Vol. 121, No. 5, pp. 848-856.
13. Valluzzi, M. R., da Porto, F. \& Modena, C. (2004). "Behavior and modeling of strengthened three-leaf stone masonry walls", Materials and Structure, Vol. 37, No. 3, pp. 184-192.

14. Valluzzi, M. R. (2007). "On the vulnerability of historical masonry structures: analysis and mitigation”, Materials and Structures, Vol. 40, No. 7, pp. 723-743.

15. Augenti, N. \& Parisi, F. (2010). "Learning from construction failures due to the 2009 L'Aquila, Italy, Earthquake", Journal of Performance of Constructed Facilities, Vol. 24, No. 6, pp. 536-555.

16. EC 8 (2005). "Eurocode 8: Design of structures for earthquake resistance, Part 3: Assessment and retrofitting of buildings", CEN-EN 1998-3.

17. NTC (2008). "NTC 2008 - Norme tecniche per le costruzioni" (in Italian), Ministerial Decree and Commentary, 14/01/2008, Italy.

18. ASCE (2006). Seismic Rehabilitation of Existing Buildings - SEI/ASCE 41-06. American Society of Civil Engineers, Reston, Va.

19. FEMA 547 (2006). Techniques for the seismic rehabilitation of existing buildings, Federal Emergency Management Agency, Washington, DC.

20. Borri, A., Corradi, M., Speranzini, E. \& Giannantoni, A. (2008). "Consolidation and Reinforcing of stone wall using a reinforced repointing grid", $6^{\text {th }}$ International Conference of Structural Analysis of Historical Construction, 2-4 July, Bath, England.

21. Dolce, M., Nigro, D., Ponzo, F. C. \& Marnetto,. R. (2001). "The CAM system for the retrofit of masonry structures", Proceedings of the $7^{\text {th }}$ International Seminar on Seismic Isolation, Passive Energy Dissipation and Active Control of Vibrations of Structures, Assisi, Italy. 